\title{
Gewald reaction: synthesis, properties and applications of substituted 2-aminothiophenes
}

\author{
Zita Puterová, ${ }^{a} *$ Alžbeta Krutošíková, ${ }^{b}$ and Daniel Végh ${ }^{c}$ \\ ${ }^{a}$ Department of Chemical Theory of Drugs, Faculty of Pharmacy, Comenius University, \\ Kalinčiakova 8, 83232 Bratislava, Slovakia \\ bepartment of Chemistry, Faculty of Natural Sciences, University of St. Cyril and Methodius, \\ Nám. J. Herdu 2, 91701 Trnava, Slovakia \\ ${ }^{\mathrm{c}}$ Institute of Organic chemistry, Catalysis and Petrochemistry, Faculty of Chemical and Food \\ Technology, Slovak University of Technology, Radlinského 9, 81237 Bratislava, Slovakia \\ E-mail:puterova@fpharm.uniba.sk
}

\begin{abstract}
Chemistry of 2-aminothiophenes is arguably one of the most extensive and dynamic field of present-day thiophene research. Since 1961 when first report on the Gewald reaction was reported it became a universal method for synthesis of substituted 2-aminothiophenes and has gained prominence in recent times. The availability of reagents and the mild reaction conditions all contribute to the versatility of this reaction. This review summarizes the synthetic strategies for substituted 2-aminothiophenes. Consequently, details about the proposed mechanism of Gewald-like reactions and the wide scope of substituted 2-aminothiophenes for real life applications.
\end{abstract}

Keywords: Gewald reaction, substituted 2-aminothiophenes, drug design, optoelectronics, dyes

\section{Table of Contents}

1. Introduction

2. Synthesis of substituted 2-aminothiophenes via Gewald reaction

2.1 The first version of the Gewald reaction

2.2 The second version of the Gewald reaction

2.3 The third version of the Gewald reaction

2.4 The fourth version of the Gewald reaction

2.5 Mechanism of the Gewald reaction

2.5.1 The ring closure

2.5.2 Base-promoted addition of sulfur 
2.5.3 Electrochemical activation of sulfur

2.5.4 Dimerization vs. cyclization

2.6 Modifications of the Gewald reaction

2.6.1 Solid-supported Gewald synthesis

2.6.2 Microwave accelerated Gewald synthesis

2.6.3 Microwave assisted Gewald synthesis on solid support

2.6.4 Synthesis of 5-halogen substituted 2-aminothiophenes

3. Utilization of substituted 2-aminothiophenes and Gewald reaction in the synthesis of condensed heterocycles

3.1 Synthesis of substituted thieno[3,4-c]thiolactones

3.2 Synthesis of substituted thieno[2,3-b]pyrroles

3.3 Synthesis of substituted thieno[2,3- $d]$ pyrimidines

3.4 Synthesis of substituted thieno[2,3- $b]$ pyridines

4. Applications of substituted 2-aminothiophenes in drug design, optoelectronics and dyes

4.1 Synthesis of pharmaceuticals and drugs

4.1.1 Synthesis of 3-deazathiamine

4.1.2 Synthesis of thieno[2,3-d][1,3]oxazin-4-ones as inhibitors of Human leukocyte elastaze

4.1.3 5-Substituted 2-aminothiophenes as $\mathrm{A}_{1}$ Adenosine receptor allosteric enhancers

4.1.4 Other important pharmaceuticals developed from 2-aminothiophenes

4.2 Synthesis of building blocks for optoelectronics

4.2.1 Synthesis of thiophene-based azometines

4.2.2 Synthesis of $\pi$-conjugated thiophenes via Gewald reaction

4.3 Synthesis of some dispersed thiophene-based azo dyes

5. Conclusions

6. Abbreviations

Acknowledgements

7. References

\section{Introduction}

Highly substituted thiophene derivatives are important heterocycles found in numerous biologically active and natural compounds. ${ }^{1-5}$ The interest in this kind of heterocycles has spread from dye chemistry ${ }^{6}$ to modern drug design ${ }^{7}$, biodiagnostics ${ }^{8}$, electronic and optoelectronic devices $^{9}$, conductivity-based sensors $^{10}$ and self-assembled superstructures. ${ }^{11}$ 2-Amino-3aroylthiophenes are agonist allosteric enhancers at the $A_{1}$ adenosine receptor. ${ }^{12,13}$ A novel class of thiophene-derived antagonists of the human glucagon receptor has been discovered. ${ }^{14}$

Traditionally, polysubstituted 2-aminothiophenes with an electron-withdrawing group such as cyano, ethoxycarbonyl or aminocarbonyl in the 3-position and alkyl, aryl or hetaryl groups in 
the 4- and 5-position are prepared utilizing the Gewald reaction. ${ }^{15}$ The core structure is formed in the multicomponent reaction between a ketone or aldehyde, an activated nitrile and sulfur in the presence of suitable base. Although this one-pot synthesis is well established, the two-step procedure in which an $\alpha, \beta$-unsaturated nitrile is first prepared by a Knoevenagel-Cope condensation of ketone or aldehyde with an activated nitrile, followed by base-promoted reaction with sulfur has been also widely employed. Generally, there are four basic variations described by Gewald and co-workers ${ }^{16-20}$ and about up to fifteen modifications to accomplish the synthesis of highly functionalized 2-aminothiophenes.

Recently, the improvements of the Gewald synthesis were announced. ${ }^{21-24}$ They are based in diminution of the reaction time by using microwave technology. The chemistry of aminothiophenes has been broadly summarized in 1986 in the monograph of R. K. Norris ${ }^{25}$ and later reviewed in $1999 .^{26}$

The importance of this field of heterocyclic chemistry gave impetus to the present study, where the data on synthesis, reactivity and application of variously substituted 2aminothiophenes are systematized and analyzed. Emphasis is given to the recent studies published, in which the most general approaches to the synthesis of basic 2-aminothiophenes via the Gewald reaction and other target structures were considered. Data of the utilization of 2aminothiophenes in the synthesis of novel type of fused heterocycles and their application are included. Particular attention is given to studies published in the previous 15-20 years.

\section{Synthesis of substituted 2-aminothiophenes}

The chemistry of 2-aminothiophenes has received much attention upon their convenient availability through the most versatile synthetic method developed by Gewald and his coworkers. ${ }^{15}$ Many methods of synthesis of substituted 2-aminothiophenes published before the Gewald are generally unsuitable because they involve difficult preparation of the starting materials, multi step synthesis and do not produce high yields. ${ }^{26}$

The prior to universal synthesis to this kind of product was reported in 1910 by Benary ${ }^{27}$ as the multi step reaction of ethyl 4-chloro-2-cyano-3-oxobutanoate $\mathbf{1}$. After the treatment of $\mathbf{1}$ with potassium hydrosulfide the reactive sufanyl-substituted intermediate $\mathbf{2}$ was created, which in the subsequent intramolecular addition of sulfanyl group to cyano group proceeded ethyl 2-amino-4hydroxythiophene-3-carboxylate 4 in equilibrium with its cyclic tautomer - the appropriate imine 3 (Scheme 1).

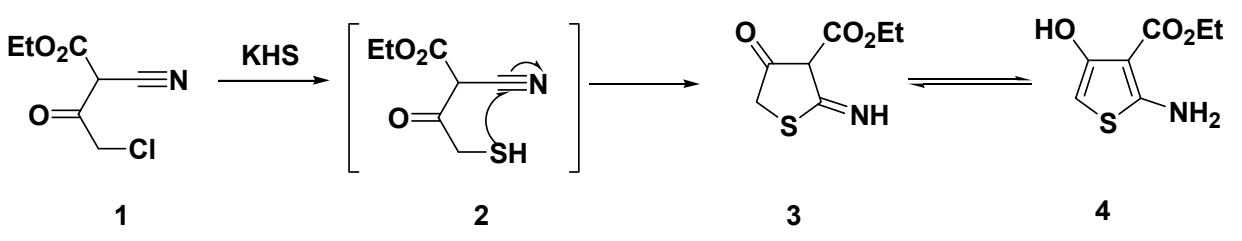

Scheme 1 
The Benary method exhibits a very limited scope because of the unavailability of halosubstrates like 1. Fifty years later, in 1961, substituted 2-aminothiophenes with electronwithdrawing substituents (such as cyano, carbonyl, methoxycarbonyl, aminocarbonyl, etc.) at the C-3 position and electron-donating substituents (such as alkyl, aryl, cycloalkyl, etc.) in the C-4 position of the thiophene ring were synthesized in a one step process from aliphatic substrates substituted $\alpha$-sulfanylaldehyde or $\alpha$-sulfanylketone 5 and $\alpha$-substituted acetonitrile $\mathbf{6}$ (where the substituent is EWG, $\mathrm{X}=\mathrm{CN}, \mathrm{CO}_{2} \mathrm{H}$, Scheme 2). ${ }^{16}$ Since then, the Gewald reaction and its variations have found enormous utility in synthesis of variety of substituted 2-aminothiophenes.

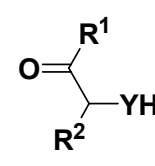

5a: $\mathrm{Y}=\mathrm{SH}$

5b: $Y=H$

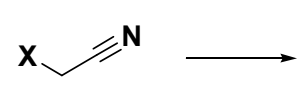

6

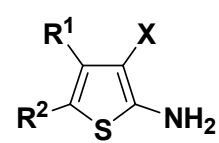

7a-f

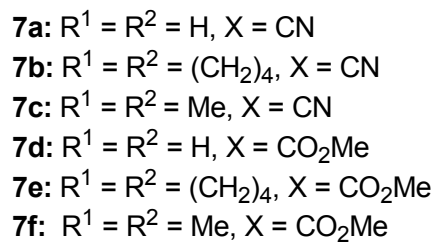

\section{Scheme 2}

The Gewald reaction represents the multi component process to prepare substituted 2aminothiophenes in generally high yields from $\alpha$-substituted acetonitriles carrying electronwithdrawing groups and $\alpha$-methylene carbonyl compounds (aldehydes or ketones) in the presence of the base - organic bases such as secondary or tertiary amines (diethylamine, morpholine, triethylamine, pyridine) or inorganic bases (e.g. $\mathrm{NaHCO}_{3}, \mathrm{~K}_{2} \mathrm{CO}_{3}, \mathrm{NaOH}$ ). Polar solvents, like DMF, alcohols (methanol, ethanol), 1,4-dioxane enhance the condensation of intermediates - $\alpha, \beta$-unsaturated nitriles with sulfur, which are either prepared in situ or externally. Depending on the used starting substrates and the reaction conditions three basic versions of the Gewald reaction have been developed ${ }^{16,28-30}$, which were lately enriched by a fourth version. ${ }^{31}$

\subsection{The first version of the Gewald reaction}

In the first version of this reaction, an $\alpha$-sulfanyladehyde or $\alpha$-sulfanylketone 5a is treated with $\alpha$-activated acetonitrile 6 in the presence of a basic catalyst (usually triethylamine or piperidine). Reaction performed in the solvents like methanol, ethanol or DMF at $50{ }^{\circ} \mathrm{C}$ takes place in two subsequent steps - Knoevenagel-Cope condensation ${ }^{32,33}$ and intramolecular ring closure of formed sulfanyl substituted $\alpha$, $\beta$-unsaturated nitrile 8 (Scheme 3).

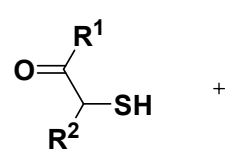

$5 \mathbf{a}$

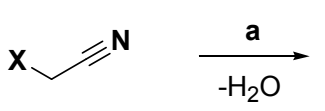

6

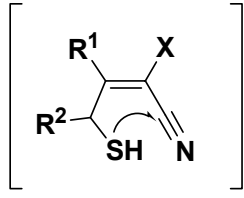

8

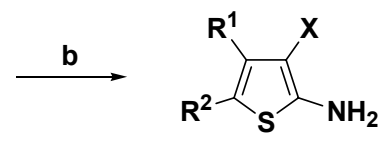

7

a: Knoevenagel-Cope condensation: triethylamine or piperidine (cat. amount), $50{ }^{\circ} \mathrm{C}$; $\mathbf{b}$ : ring-closure reaction.

Scheme 3 
By this reaction polysubstituted 2-aminothiophenes 7 with electron-donating substitents in C4 and C-5 positions of the thiophene $\operatorname{ring}\left(\mathrm{R}^{1}\right.$ and $\mathrm{R}^{2}$, mainly alkyl and cycloalkyl chains) are prepared in yields varying between $35-80 \%$ (Table 1). ${ }^{15,16,28-30}$ Because of the instability and difficult preparation of the starting $\alpha$-sulfanylcarbonyl compounds $5 \mathbf{a}$ this reaction appears to have a limited scope and more convenient variations are utilized instead of this procedure.

Table 1. Some of substituted 2-aminothiophenes 7 prepared by the version 1 of the Gewald reaction

\begin{tabular}{cccccc}
\hline $\mathrm{R}^{1}$ & & $\mathrm{R}^{2}$ & $\mathrm{X}$ & Yield (\%) & Reference \\
\hline $\mathrm{Me}$ & & $\mathrm{Et}$ & $\mathrm{CN}$ & 51 & 15 \\
$\mathrm{Me}$ & & $\mathrm{Me}$ & $\mathrm{CN}$ & 70 & 15 \\
& $\left(\mathrm{CH}_{2}\right)_{4}$ & & $\mathrm{CN}$ & 70 & 16 \\
$\mathrm{Me}$ & & $\mathrm{Me}$ & $\mathrm{CO}_{2} \mathrm{Me}$ & 45 & 28 \\
& $\left(\mathrm{CH}_{2}\right)_{4}$ & & $\mathrm{CO}_{2} \mathrm{Et}$ & 80 & 29 \\
\hline
\end{tabular}

\subsection{The second version of the Gewald reaction}

The second version of the Gewald's process is the most elegant and consists of the one-pot reaction of three components - $\alpha$-methylene carbonyl compound $\mathbf{5 b}, \alpha$-activated acetonitrile $\mathbf{6}$ and sulfur at a temperature not exceeding $45^{\circ} \mathrm{C}$ in ethanol or methanol. In this case the base, mainly secondary amine (diethylamine, morpholine), is used in 0.5-1.0 molar equivalent amounts. Reaction towards substituted 2-aminothiophenes with an electron-withdrawing substituent in position C-5 $\left(\mathrm{R}^{2}\right)$ occurs within three base-promoted steps: condensation of starting substrates $\mathbf{5 b}$ and $\mathbf{6}$ - addition of sulfur to $\alpha$, $\beta$-unsaturated nitrile $\mathbf{9}$ - ring-closure of the ylidenesulfur adduct 10 (Scheme 4). ${ }^{17,26,33,34}$

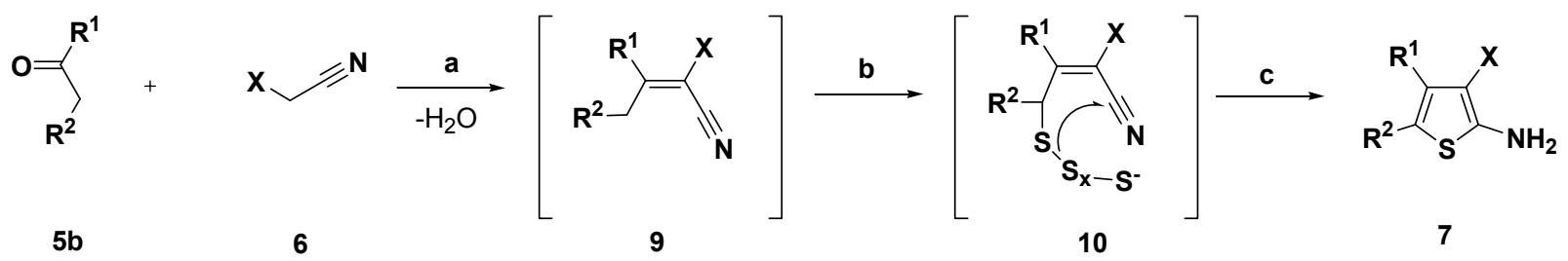

a: Knoevenagel-Cope condensation: diethylamine or morpholine (0.5 - 1.0 equiv. amount), $\mathrm{MeOH}$ or EtOH, RT - $45^{\circ} \mathrm{C}$; b: addition of sulfur, $\mathrm{S}_{8}(1.0$ equiv. amount); c: ring-closure.

\section{Scheme 4}

Since the yields are higher than in the first version (45-95\%) and the reactants are easily available and non-expensive compounds by this reaction variously substituted 2aminothiophenes, predominantly with EWG and aromatic substituents in C-5 position of formed thiophene ring (substituent $\mathrm{R}^{2}$ ), are obtainable by a very comfortable manner (Table 2 ). 
Table 2. Some of substituted 2-aminothiophenes 7 prepared via the Version 2 of the Gewald reaction

\begin{tabular}{ccccc}
\hline $\mathrm{R}^{1}$ & $\mathrm{R}^{2}$ & $\mathrm{X}$ & Yield (\%) & Reference \\
\hline $\mathrm{Me}$ & $\mathrm{COMe}$ & $\mathrm{CO}_{2} \mathrm{Me}$ & 50 & 17 \\
$\mathrm{NH}_{2}$ & $\mathrm{CO}_{2} \mathrm{Et}$ & $\mathrm{CO}_{2} \mathrm{Et}$ & 45 & 17 \\
$\mathrm{Me}$ & $\mathrm{CO}_{2} \mathrm{Et}$ & $\mathrm{CO}_{2} \mathrm{Et}$ & 60 & 17 \\
$\mathrm{Ph}$ & $\mathrm{Ph}$ & $\mathrm{CN}$ & 95 & 34 \\
$\mathrm{SO}_{2} \mathrm{Ph}$ & $4-\mathrm{BrC}_{6} \mathrm{H}_{4}$ & $\mathrm{CN}$ & 84 & 17 \\
\hline
\end{tabular}

\subsection{The third version of the Gewald reaction}

The third two-step version of the Gewald reaction allows the reaction of alkyl-aryl or cycloalkyl ketones which exhibit limited reactivity under the one-pot conditions. $\alpha$, $\beta$-Unsaturated nitrile 9 as a product of Knoevenagel-Cope condensation is previously prepared and isolated and then treated with sulfur and amine (Scheme 5). ${ }^{35-37}$

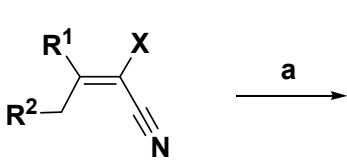

9

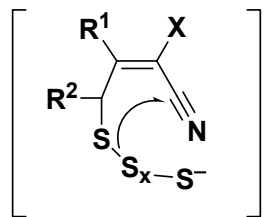

10

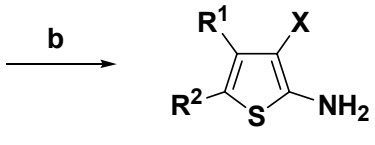

7

a:Addition of sulfur: secondary or tertiary amine, $\mathrm{S}_{8}\left(1.0\right.$ equiv. amount); $\mathrm{MeOH}$ or EtOH, RT- $50{ }^{\circ} \mathrm{C}$; b: ring-closure; $\mathbf{X}=\mathrm{CO}_{2} \mathrm{Me}, \mathrm{CO}_{2} \mathrm{Et}, \mathrm{CN}, \mathrm{CO}_{2} \mathrm{H}, \mathrm{CO}_{2}$-t-Bu.

\section{Scheme 5}

Alkyl aryl ketones and some cycloalkyl ketones which are not reactive under the one-pot modifications (version 1 or version 2) give acceptable yields of thiophenes in the two-step procedure (Table 3).

Table 3. 2-Aminothiophenes achievable by the Version 3 of the Gewald reaction

\begin{tabular}{cccc}
\hline $\mathrm{R}^{1} / \mathrm{R}^{2}$ & $\mathrm{X}$ & Yield (\%) & Reference \\
\hline $\mathrm{CN}$ & $\mathrm{CN}$ & 51 & 37 \\
& $\mathrm{CN}$ & 58 & 37 \\
$\mathrm{CO}_{2} \mathrm{Et}$ & 79 & 37 \\
\hline
\end{tabular}




\subsection{The fourth version of the Gewald reaction}

The last from the basic Gewald's methods represents the latest improvement of the first version. In this particular version the more stable dimeric forms of an $\alpha$-sulfanylcarbonyl compound substituted 1,4-dithiane-2,5-diols 5c undergo condensation and subsequent cyclization with $\alpha$ activated acetonitrile 6 requiring an amine in stochiometric amount (Scheme 6).

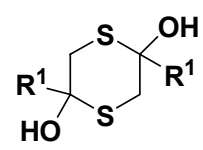

$5 c$

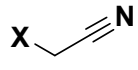

6
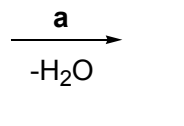

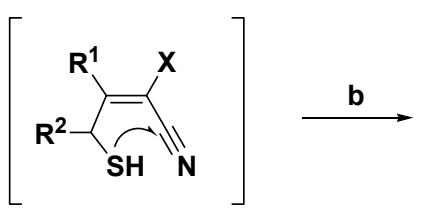

8

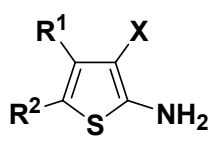

7

a:Condensation: secondary or tertiary amine (1.0 equiv. amount), methanol, $\mathrm{RT}-50^{\circ} \mathrm{C}$;

b: ring-closure; $\mathrm{R}^{1}=\mathrm{H}$ or alkyl, $\mathrm{R}^{2}=\mathrm{H}$.

\section{Scheme 6}

Priority of this major modification is the preparation of mono- or disubstituted 2aminothiophenes with free $\alpha$-position of formed thiophene ring $\left(\mathrm{R}^{2}=\mathrm{H}\right.$, Table 4$)$ in satisfactory yields (Table 4$).^{31,38}$

Table 4. Substituted 2-aminothiophenes obtainable using the Version 4 of the Gewald reaction

\begin{tabular}{ccccc}
\hline $\mathrm{R}^{1}$ & $\mathrm{R}^{2}$ & $\mathrm{X}$ & Yield (\%) & Reference \\
\hline $\mathrm{H}$ & $\mathrm{H}$ & $\mathrm{CO}_{2} \mathrm{Me}$ & 58 & 31 \\
$\mathrm{Me}$ & $\mathrm{H}$ & $\mathrm{Me}$ & 52 & 31 \\
$\mathrm{H}$ & $\mathrm{H}$ & $\mathrm{CN}$ & 72 & 38 \\
$\mathrm{H}$ & $\mathrm{H}$ & $\mathrm{CONH}_{2}$ & 46 & 38 \\
$\mathrm{Me}$ & $\mathrm{H}$ & $\mathrm{Me}$ & 81 & 31 \\
\hline
\end{tabular}

\subsection{Mechanism of the Gewald reaction}

Even if the several reviews and papers on the Gewald reaction and its improvements have been reported in the literature ${ }^{39-51}$ the mechanism of this reaction is not fully clear. As it is presented on Schemes 3-6, the substituted 2-aminothiophene ring is formed from the aliphatic starting substrates during the multi step reaction sequence: condensation - addition of sulfur - ringclosure. Depending on the type of the used reactants, in some variations of the reaction, the condensation (Version 3) or addition of sulfur step (Versions 2 and 4) is not required.

2.5.1 The ring closure. The most crucial step in all cases of the basic Gewald reaction and its improvements is the final ring-closure process, which is performed as an intramolecular nucleophilic attack of the sulfur anion to triple bond of the cyano group (Scheme 7). Target 2aminothiophenes 7 in principle exists in equilibrium with the tautomeric forms - cyclic imines 
11 formed during the cyclization. It was proved, that the parent aminothiophene occurs exclusively in the amino form. ${ }^{52-56}$

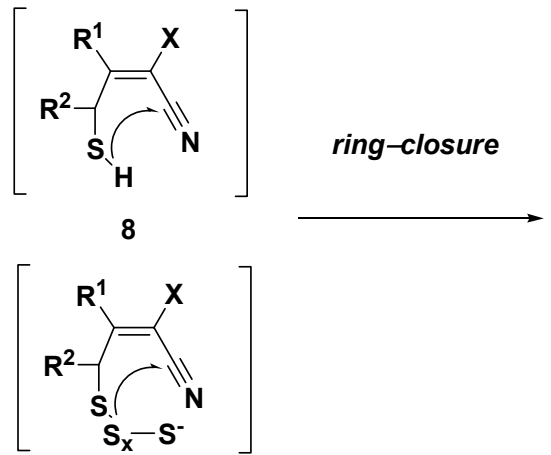

10

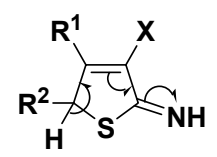

11
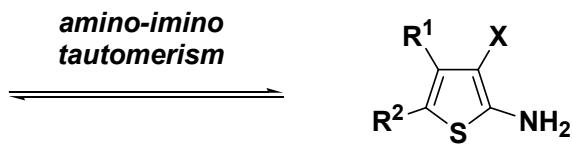

7

\section{Scheme 7}

In fact, the reaction of the addition of sulfur to $\alpha, \beta$-unsaturated nitrile 9 , which is required almost in all types of the Gewald reaction except the versions 1 and 4 where the starting compounds are already sulfanyl substituted (compounds 5a and 5c), is not known in detail. However, it is sure, that $S_{8}$ has to be activated to react with Knoevenagel-Cope product 9. Some authors report that the activation of sulfur and the following addition of sulfur on a methylene group is base-promoted ${ }^{57-59}$, others detail the electrochemical activation of the $\mathrm{S}_{8}{ }^{60-62}$

2.5.2 Base-promoted addition of sulfur. In the base-promoted addition the elemental sulfur reacts with amines to yield polysulfide anions, that can behave as nucleophiles. ${ }^{63,64}$ The methylene group of appropriate $\alpha, \beta$-unsaturated nitrile 9 is being deprotonated first and then sulfur addition takes place (Scheme 8). The most suitable base for the activation with sulfur and the subsequent sulfur addition morpholine has been proved. ${ }^{59}$ The morpholine exhibits the best solubility of sulfur from the entire organic base used in Gewald reaction. Additionally, by mixing the morpholine with sulfur at $150{ }^{\circ} \mathrm{C}$ the morpholine polysufide (MPS) is formed, which structure is presumed to contain from 2 - 5 sulfur atoms within two morpholine molecules. ${ }^{57,65}$ MPS acts then in two ways - as a base needed in each reaction step, and also as a $S$-nucleophile in the addition of sulfur step to the $\alpha, \beta$-unsaturated substrate 9 to create reactive ylidene sulfur adduct $\mathbf{1 0}$ (Scheme 8). 


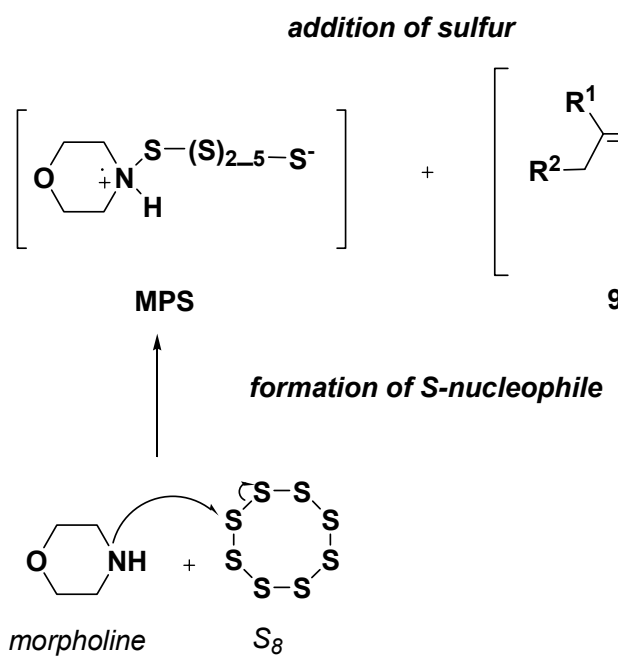

ring-closure

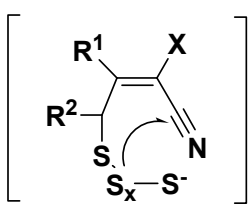

10

9 $[\overbrace{}^{+}{ }^{H}$

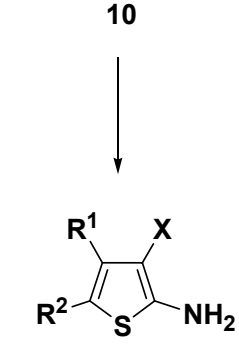

7

\section{Scheme 8}

2.5.3 Electrochemical activation of sulfur. In this relatively new synthetic pathway the sulfur, which is electro active, is incorporated in a carbon electrode and used as a sacrificial cathode to yield $\mathrm{S}_{3}{ }^{-}, \mathrm{S}_{8}{ }^{--}$and $\mathrm{S}_{4}{ }^{2-} \cdot{ }^{60,61}$ In an upgraded way the cyanomethyl anion $\left({ }^{-} \mathrm{CH}_{2} \mathrm{CN}\right)$ is generated by galvanostatic reduction of acetonitrile solution (in a mixture with supporting electrolyte tetraethyl ammonium hexafluorophosphate - TEAHFP). ${ }^{62}$ Formed anion $\left(\mathrm{CH}_{2} \mathrm{CN}\right)$ is highly reactive and represents the basic species necessary to activate $\mathrm{S}_{8}$ and form $S$-cyanomethyl anion acting as a promoter of the ylidene sulfur intermediate of the structure 12 (Scheme 9).
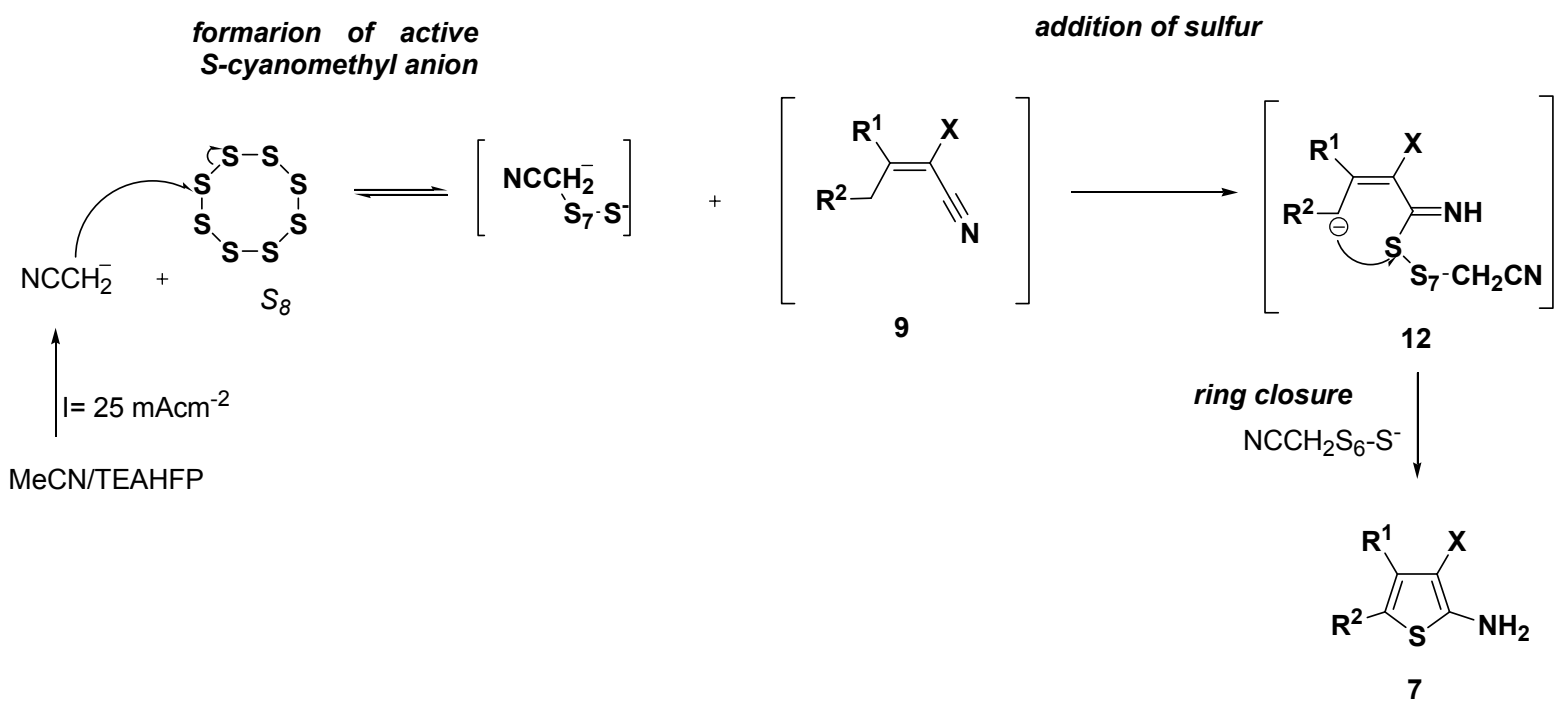

\section{Scheme 9}


Comparing the process of electrochemical activation to standard base-promoted addition of sulfur, the ylidene sulfur adduct $\mathbf{1 2}$ is formed by addition of a $S$-cyanomethyl anion onto the cyano group (Scheme 9), while in the previous version the polysulfide-like anion affects the methylene group of the $\alpha, \beta$-unsaturated nitrile $\mathbf{1 0}$ (Scheme 8). However, if the activation with sulfur does not occur properly, the ylidene-sulfur adduct of presumed structure $\mathbf{1 0}$ or $\mathbf{1 2}$ is not formed and the side-reaction takes place.

2.5.4 Dimerization vs. cyclization. It is presumed, that the dimerization of Knoevenagel-Cope product - the $\alpha$, $\beta$-unsaturated nitrile 9 to six membered hexa-1,3-diene 14 occurs spontaneously as a side-reaction in the Gewald's process (Scheme 10). ${ }^{66}$ The yield of a dimer 14 is highly dependent on the reaction conditions. While in some cases the ylidene dimerization is significant and the by-product is isolated in higher yield than the desired 2 -aminothiophene derivative ${ }^{58}$, on other hand under suitable reaction conditions not only is the straightforward reaction favored, but also the recyclization of dimerized ylidene $\mathbf{1 4}$ to appropriate aminothiophene $\mathbf{7}$ occurs. ${ }^{59}$ The dimer 14 preferably is formed in the less studied, so-called redesigned Gewald procedure which is suitable for preparation six-membered carbonitriles with a free amino group. ${ }^{67}$ If the reaction is directed towards formation of derivatives 14, the anion generated from the $\alpha, \beta$-unsaturated nitrile 9 undergoes first to base-promoted Michael addition which is followed by Thorpe cyclization of the adduct 13 to create cyclohexadiene system 14 (Scheme 10). ${ }^{68}$

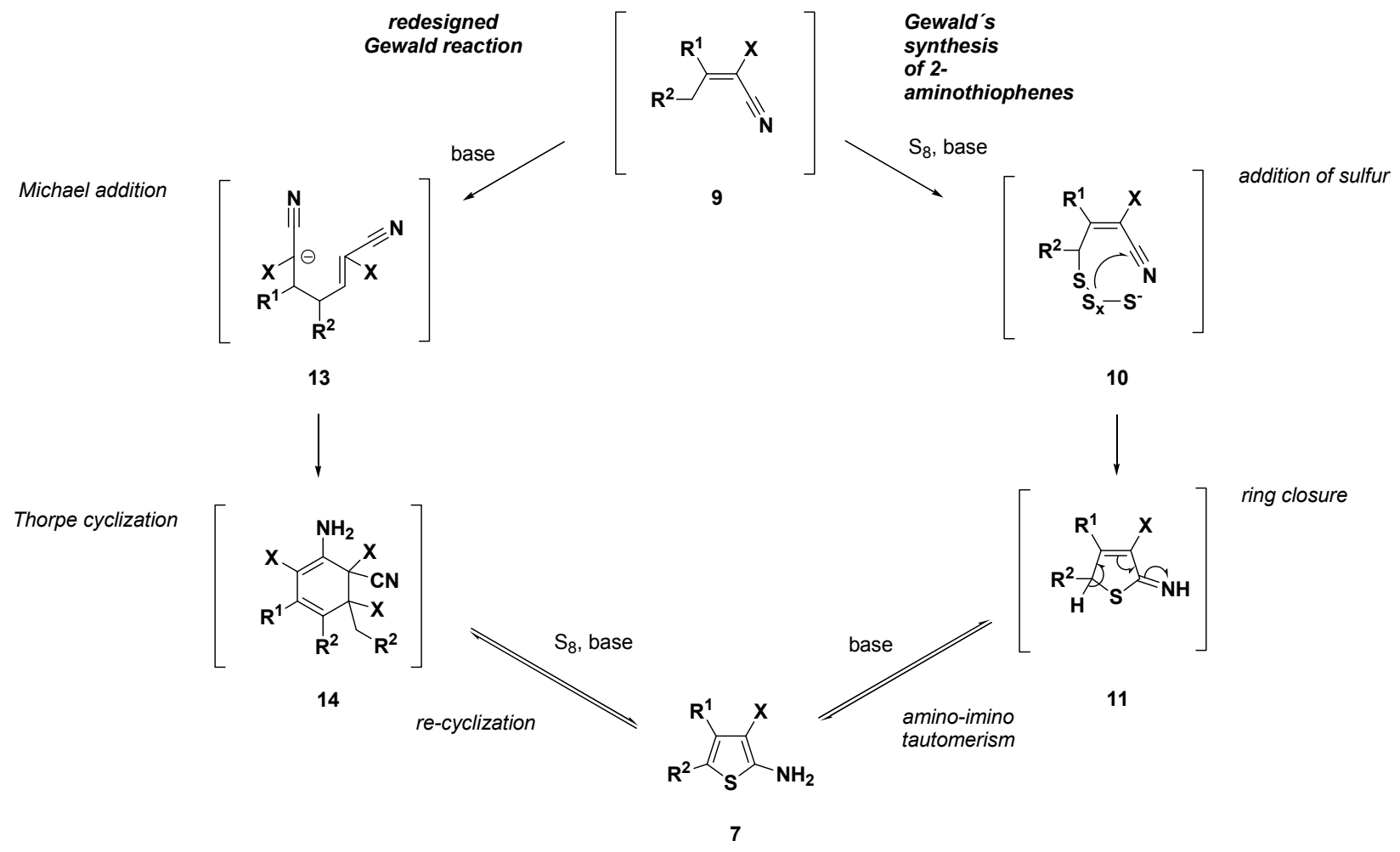

Scheme 10 


\subsection{Modifications of the Gewald reaction}

From the analyses of four major versions and the mechanism of the Gewald reaction (Contents 2.1-2.5 ) it is evident that, even if the experimental preparation represents a simple procedure, the sequence of the production of intermediates is not known and can change depending on variable reaction conditions. Because of the tremendous utility of substituted 2-aminothiophenes not only in organic synthesis but also in several applied fields, from the time of the discovery of Gewald's method until today many of its new variations have been developed. By the use of improved methods and modified experimental procedures the scope of easily obtainable 2aminothiophenes ultimately spread. More complex starting substrates, especially starting carbonyl derivatives, such as azepinones ${ }^{69}$, indanones ${ }^{39}$, pyranones $^{70}, \alpha$ - and $\beta$ - tetralones ${ }^{71}$ and many other types ${ }^{72-75}$ undergo the modified Gewald reaction.

Exploiting the reaction conditions with starting substrates tolerating a broad range of functional groups and alkyl, aryl and heteroaryl substituents about 15 new modifications of the Gewald reaction can be found in literature. ${ }^{76-82}$ As it was reported by the authors ${ }^{58}$ the use of inorganic bases (e.g. $\mathrm{Na}_{2} \mathrm{CO}_{3}, \mathrm{NaOH}, \mathrm{NaHCO}_{3}, \mathrm{~K}_{3} \mathrm{PO}_{4}$ ) instead of organic base (morpholine, pyridine, triethylamine) facilitates of the ylidene-sulfur intermediate formation and the ring closure in two-step version of the Gewald reaction (version 3, Content 2.3).

Other researchers ${ }^{50}$ deal that the use acid-base catalyst (ammonium salts: acetates and trifluoroacetates of diethylammonium, morpholinium, piperidinium) promotes the creation of the Knoevenagel-Cope condensation product ( $\alpha$, $\beta$-unsaturated nitrile) and enhances the yield of final 2-aminothiophene. Ionic liquids used as solvents in combination with ethylenediammonium diacetate were shown to be very efficient in the case of the Gewald synthesis with aliphatic and alicyclic ketones with possibility of regeneration of used liquids. ${ }^{83}$

From all of these novel optimizations the most effort is focused on solid-supported synthesis ${ }^{86}$ and microwave accelerated the Gewald reaction. ${ }^{24}$

2.6.1 Solid-supported Gewald synthesis. Heterogeneous organic reactions using reagents immobilized on porous solid supports have been often proved advantageous over conventional solution phase reactions because of good dispersion of active reagent sites, better selectivity and easier work-up. One of such reagents is commercially available AgroGel ${ }^{\circledR}$ Wang resin, ${ }^{84}$ the grafted (polyethylene glycol) polystyrene -PEG-PS. The benefits of the PEG-PS Wang linker during the Gewald synthesis have been highlighted by the authors ${ }^{85}$ in synthesis of substituted 2aminothiophenes with carboxylic acid functionality in the neighboring $\beta$-position. It was found, that appropriate esters of some Gewald products proved difficult to hydrolyze via traditional saponification. The acylation of AgroGel $^{\circledR}$ Wang resin 15 with cyanoacetic acid 16 under standard DIC/DMAP coupling conditions gave the resin-bound cyanoacetic ester 17. After the dispersion of reagent 17 in ethanol Gewald reaction was performed in Quest ${ }^{\mathrm{TM}} 210$ synthesizer by mixing with the starting compound - $\alpha$-methylene carbonyl compounds 18 and substrates sulfur and morpholine. Final 2-aminothiophene carboxylic acids were isolated as $\mathrm{N}$-acetyl 
protected derivatives 20 (Table 5) upon the cleavage of the resin with trifluoroacetic acid (Scheme 11).

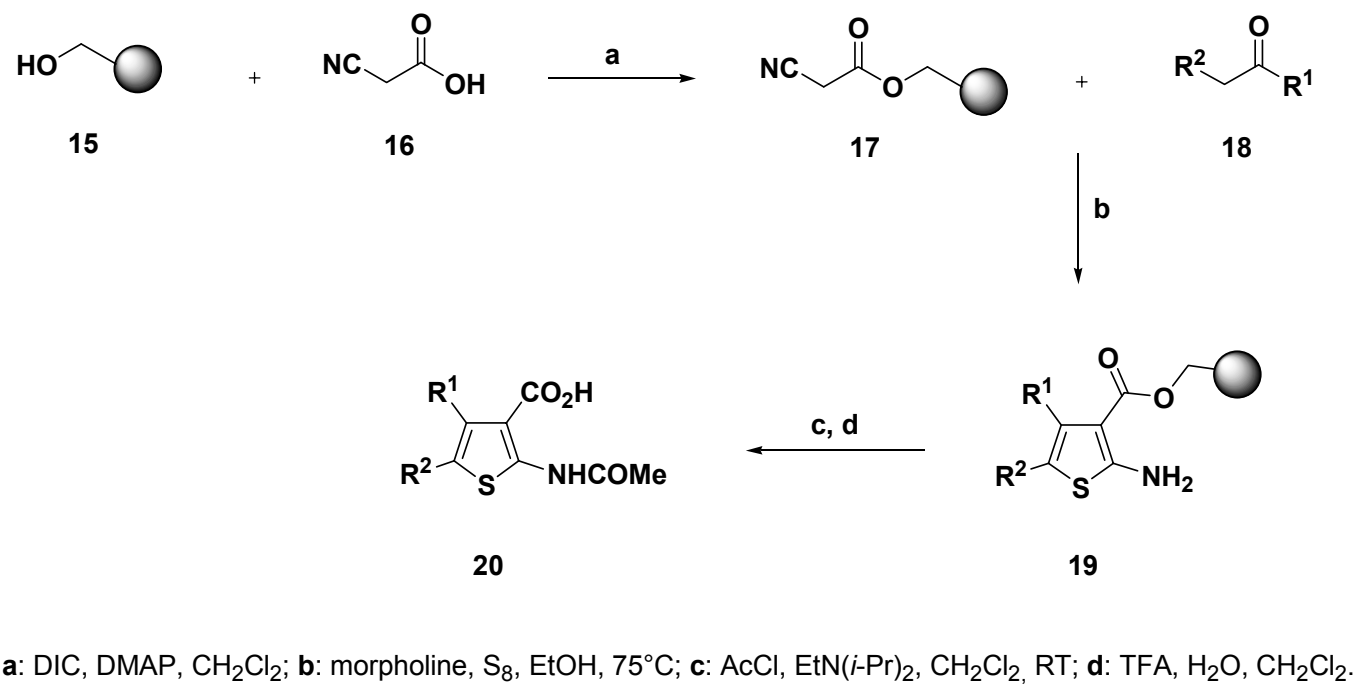

\section{Scheme 11}

Table 5. Substituted 2-aminothiophenes 20 achieved during the solid-supported Gewald's synthesis

Aldehyde/Ketone 18 Yield (\%)


2.6.2 Microwave accelerated Gewald synthesis. Most of the published Gewald synthetic procedures required long reaction times varying between 4 and $48 \mathrm{~h}$. Microwave heating is an area of increasing interest in both academic and industrial laboratories because it can raise the rate of reaction and in many cases improve product yields. ${ }^{86,87}$ The expeditious Gewald synthesis under microwave irradiation was applied for preparation of 2-aminothiophenes without the substituents in position C-4 and C-5 of thiophene ring. This process represents the advancement of the basic version 4 (content 2.4). Reaction starting from 1,4-dithiane-2,5-diol 21 and $\alpha$ activated acetonitrile 6 was completed after $2 \mathrm{~min}$. in methanol with triethylamine used as a base (Scheme 12). ${ }^{24}$ Compared to classical reaction conditions ${ }^{16,31,38,88}$ the appropriate monosubstituted 2-aminothiophenes $\mathbf{2 2}$ were obtained in higher yields with significantly shorter reaction time (Table 6).

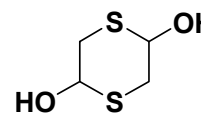

21

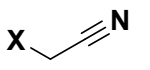

6

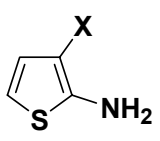

22

a: $\mathrm{Et}_{3} \mathrm{~N}, \mathrm{MeOH}, 50^{\circ} \mathrm{C}$, microwave, 2 min.

\section{Scheme 12}

Table 6. Monosubstituted 2-aminothiophenes 22 obtained under the microwave assisted Gewald reaction

\begin{tabular}{ccc}
\hline $\mathrm{X}$ & $\begin{array}{c}\text { Yield (\%)/ } \\
\text { Reference } \\
\text { Microwave reaction }\end{array}$ & $\begin{array}{c}\text { Yield (\%)/ Reference } \\
\text { Classical conditions }\end{array}$ \\
\hline $\mathrm{CO}_{2} \mathrm{Me}$ & $82[24]$ & $55[31]$ \\
$\mathrm{CONH}{ }_{2}$ & $78[24]$ & $78[88]$ \\
$\mathrm{CONHPh}$ & $87[24]$ & $55[16]$ \\
$\mathrm{CO}-t-\mathrm{Bu}$ & $81[24]$ & - \\
$\mathrm{CN}$ & $60[24]$ & $58[31]$ \\
\hline
\end{tabular}

2.6.3 Microwave assisted Gewald synthesis on solid support. Microwave enhanced Gewald reaction in combination with solid-support accelerated method was presented as an easy access to polysubstituted 2-aminothiophenes. ${ }^{89,99}$ A variety of ketones $\mathbf{5}$ were reacted with ethyl cyanoacetate $\mathbf{6 a}$ or malononitrile $\mathbf{6 b}$ and sulfur in the presence of KF-alumina. ${ }^{89} \mathrm{KF}$ immobilized on $\mathrm{Al}_{2} \mathrm{O}_{3}$ represents the heterogeneous catalyst with advantageous properties like better selectivity and easier work upon its use. ${ }^{90}$ The application of KF-alumina to a wide range of organic reactions has provided more convenient and efficient methods in organic syntheses. ${ }^{91-95}$ 
Its benefits arise from the strongly basic nature of $\mathrm{KF} / \mathrm{Al}_{2} \mathrm{O}_{3}$, which has allowed it to replace organic bases in a number of reactions. ${ }^{96-98}$ The reaction towards substituted 2-aminothiophenes 23 using $\mathrm{KF} / \mathrm{Al}_{2} \mathrm{O}_{3}$, was studied under microwave irradiation as well as under conventional heating (Scheme 13). ${ }^{89} \mathrm{KF}$-alumina as a base used in Gewald synthesis proceeded well producing 2-aminothiophene derivatives $\mathbf{2 3}$ in good yields. Using the microwave irradiation reaction was carried out in very short times, but alternatively the reaction proceed well also under conventional heating (Table 7).

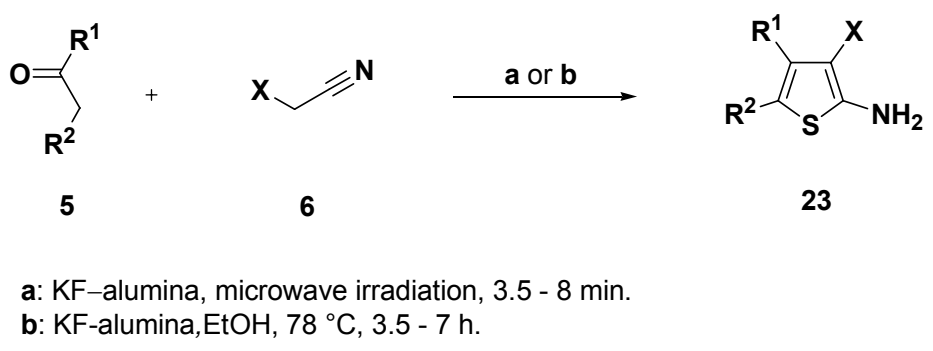

\section{Scheme 13}

Table 7. KF-alumina supported synthesis of 2-aminothiophenes $\mathbf{2 3}$ under a) microwave irradiation and b) conventional heating

\begin{tabular}{ccccc}
\hline $\mathrm{R}^{1}$ & $\mathrm{R}^{2}$ & $\mathrm{X}$ & $\begin{array}{c}\text { Yield (\%) } \\
\text { Microwave irradiation } \\
\text { (Reaction time/min) }\end{array}$ & $\begin{array}{c}\text { Yield (\%) } \\
\text { Conventional heating } \\
\text { (Reaction time/h) }\end{array}$ \\
\hline $\mathrm{Me}$ & $\mathrm{Me}$ & $\mathrm{Me}$ & $57(3.5)$ & $53(4.0)$ \\
$\mathrm{Me}$ & $\mathrm{CO}_{2} \mathrm{Et}$ & $\mathrm{CO}_{2} \mathrm{Et}$ & $58(3.5)$ & $50(4.0)$ \\
$\mathrm{Me}$ & $\mathrm{CO}_{2} \mathrm{Et}$ & $\mathrm{CN}$ & $58(3.5)$ & $55(4.0)$ \\
$\mathrm{Ph}$ & $\mathrm{H}$ & $\mathrm{CO}_{2} \mathrm{Et}$ & $61(7.5)$ & $55(4.0)$ \\
$\mathrm{Ph}$ & $\mathrm{H}$ & $\mathrm{CN}$ & $66(7.5)$ & $61(4.0)$ \\
$\mathrm{H}$ & $\mathrm{Et}$ & $\mathrm{CO}_{2} \mathrm{Et}$ & $62(6.0)$ & $48(4.0)$ \\
\hline
\end{tabular}

A number of tetrasubstituted $N$-methoxy-2-acetylaminothiophenes $\mathbf{2 6}$ with free carboxylic acid functionality in $\beta$-position next to protected amino group were achieved via a one-pot microwave assisted Gewald reaction on solid-support. ${ }^{99}$ The same Wang type ester linkage ${ }^{84}$ was used as was discussed previously. ${ }^{85}$ The Gewald reaction of the resin-bound cyanoacetic ester 17 with substituted ketones $\mathbf{5}$ and sulfur was accomplished under the microwave conditions using DBU as a base in toluene. The protection of amino group was performed with methyl 2-chloro-2oxoacetate 24 in toluene in the presence of diisopropylethylamine (DIPEA) again under the microwave irradiation. Formed resin-linked methyl oxo(2-thienylamino)acetates $\mathbf{2 5}$ were cleaved with trifluoroacetic acid in water-dichloromethane solution into substituted 2$\left\{[\right.$ methoxy(oxo)acetyl]amino $\}$ thiophene-3-carboxylic acids 26 (Scheme 14). ${ }^{99}$ The applicability 
and efficiency of one-pot microwave assisted Gewald reaction on Wang-type solid support is presented in Table 8.<smiles>N#CCC(=O)OCc1ccccc1</smiles>

16<smiles>[R]CC([R])=O</smiles>

17

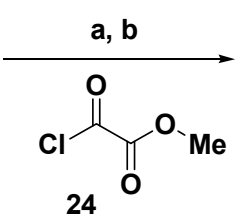

24<smiles>[R]c1sc(NC(=O)COC(C)=O)c(C(=O)OCc2ccccc2)c1[R]</smiles>

c

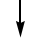<smiles>[R]c1sc(NC(=O)C(C)=O)c(C(=O)O)c1[R]</smiles>

26

a: $\mathrm{S}_{8}, \mathrm{DBU}$, toluene, microwave irradiation, $20 \mathrm{~min}$.

b: $i-\mathrm{Pr}_{2} \mathrm{EtN}$.toluene, microwave, $10 \mathrm{~min}$.

c: TFA, $\mathrm{H}_{2} \mathrm{O}, \mathrm{CH}_{2} \mathrm{Cl}_{2}$

\section{Scheme 14}

Table 8. Gewald synthesis of 2-acetylaminothiophenes on solid support under microwave irradiation

\begin{tabular}{llll}
\hline Starting compound Product & Yield (\%) & $\begin{array}{l}\text { HPLC } \\
\text { purity (\%) }\end{array}$ \\
\hline & 90 & 82 \\
& & 90 \\
\end{tabular}

2.6.4 Synthesis of 5-halogen substituted 2-aminothiophenes. It has to be mentioned, that from the enormous publications dealing with the variations of the Gewald reaction and reaction itself, 
none of them is focused on the direct synthesis of 5-halogen substituted 2-aminothiophenes. Finally, in 2003 Scammells and co-workers ${ }^{100}$ have presented the synthetic pathway to 5-bromo substituted 2-aminothiophenes 29. The reaction was successful it the R-substituted 2-bromo-1phenylethanones 27 were reacted with 3-oxo-3-phenylpropanenitrile $\mathbf{2 8}$ and sulfur in the presence of diethylamine as a base in ethanol (Scheme 15). Because of the inconvenient conditions such as strong base, longer reaction time and difficult purification, the target 5bromo-2-aminothiophenes $\mathbf{2 9}$ were obtained only in moderate yields (Table 9).
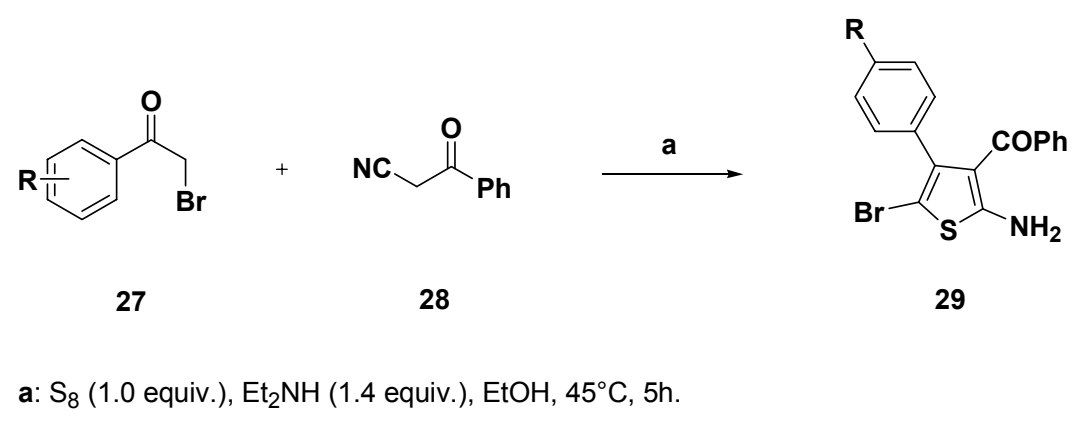

29

\section{Scheme 15}

Table 9. 5-Bromo-substituted 2-aminothiophenes 29

\begin{tabular}{ll}
\hline $\mathrm{R}$ & Yield (\%) \\
\hline $3-\mathrm{CF}_{3} \mathrm{C}_{6} \mathrm{H}_{4}$ & 48 \\
$3-\mathrm{NO}_{2} \mathrm{C}_{6} \mathrm{H}_{4}$ & 30 \\
$4-\mathrm{CF}_{3} \mathrm{C}_{6} \mathrm{H}_{4}$ & 52 \\
$4-\mathrm{NO}_{2} \mathrm{C}_{6} \mathrm{H}_{4}$ & 33 \\
$4-\mathrm{CNC}_{6} \mathrm{H}_{4}$ & 58 \\
4- $\mathrm{PhC}_{6} \mathrm{H}_{4}$ & 48 \\
2-naphtylC $6 \mathrm{H}_{4}$ & 39 \\
\hline
\end{tabular}

Later, the same research group ${ }^{101}$, have reported on synthesis of two 5-bromo substituted 2aminothiophenes 35 (Table 10) via a two-step Gewald synthesis. In a reaction of 3trifluoromethylacetophenone $\mathbf{3 0}$ with either benzoylacetonitrile or ethyl cyanoacetate $\mathbf{3 1}$ in the presence titanium(IV) chloride $^{102}$ afforded Knoevenagel-Cope product 32. In subsequent treatment of $\mathbf{3 2}$ with sulfur the 2-aminothiophene core $\mathbf{3 3}$ is formed under basic conditions. The free C-5 position of derivative 33 is substituted with bromine in two following steps - first the free amino group is being Boc protected and then C-5 position brominated with $N$ bromosuccinimide (Scheme 16). ${ }^{101}$

The substituted thiophenes 35 were obtained in favorable yields (96 and 99\%, Scheme 16). Synthesized 5-bromo substituted 2-aminothiophenes $\mathbf{2 9}$ and $\mathbf{3 5}$ were investigated as a precursors in the development of new synthetic adenosine $A_{1}$ receptor agonists with similar activity to those 
which are already acting as successful therapeutics (marketed as Adenocard ${ }^{\mathrm{TM}}$ and Tecadenoson $\left.^{\mathrm{TM}}\right) .{ }^{100,101}$

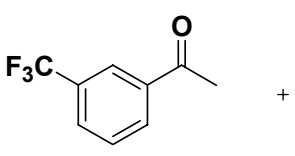

30

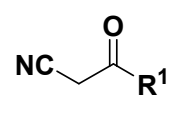

31

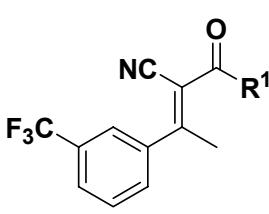

32

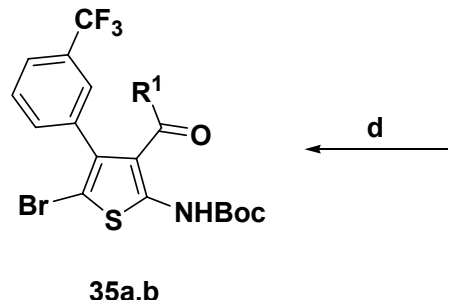

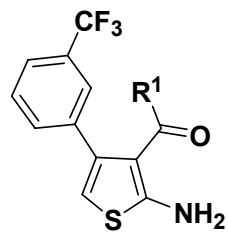

33

$\downarrow c$

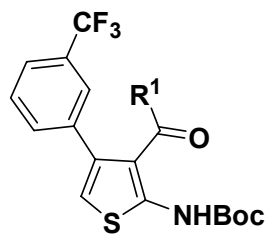

34

\section{Scheme 16}

\section{Utilization of substituted 2-aminothiophenes and Gewald reaction in the synthesis of condensed heterocycles}

The substituted 2-aminothiophenes found enormous utility in dye chemistry ${ }^{104}$, modern drug $\operatorname{design}^{105}$, biodiagnostics ${ }^{106}$, electronic and optoelectronic devices ${ }^{107}$, conductivity-based sensors ${ }^{108}$, and self-assembled superstructures. ${ }^{109}$ They are unique for their simple synthesis, environmental stability, wide spread possibility of functioning and moreover, they posses good workability and satisfactory solubility in both organic and aqueous media. The versatility of title compounds as a synthetic entry to fused heterocycles such as thieno[3,4-c]thiolactones, thieno[2,3-b]pyrroles, thieno[2,3- $d]$ pyrimidines and thieno[2,3-b]pyridines is highlighted in following chapters.

\subsection{Synthesis of substituted thieno[3,4-c]thiolactones}

The synthesis of a series of substituted thieno[3,4-c]thiolactones 39a-c as an unusual bicyclic 5:5 heteropentalene systems was reported by authors ${ }^{110}$. Starting from substituted 2-aminothiophenes 36a-c, the target fused heterocyclic derivatives 39a-c was prepared in a four step reaction sequence. The free amino group is acylated first and then the methyl group in C-4 position undergoes the radical bromination to create the crucial intermediates 37a-c. The reaction of corresponding bromomethylated thiophenes 37a-c with thiourea in acetone proceeded thiouronium salts 38a-c in almost quantitative yields. The cyclization to a fused thiophene- 
thiolactone system can be performed either using methanol-aqueous $1: 1$ solution of $\mathrm{NaHCO}_{3}{ }^{110}$ or in $1 \mathrm{M}$ water solution of $\mathrm{NaHCO}_{3}{ }^{111}$ In the first case reaction occurs selectively and only desired thieno[3,4-c] thiolactones 39a-c are being formed. In a second approach the unselective reaction proceeding takes place and the mixture of three compounds $39 a, 40$ and $\mathbf{4 1}$ are created (Scheme 17). Even if the yields of thieno[3,4-c]thiolactones 39a-c are only about $50 \%$, the presented procedure is the unique in organic synthesis and represents the easy route to such fused heteroaromatic systems and best to our knowledge only two other reports deals about the similar structures. $^{112,113}$ In addition, thieno[3,4-c] thiolactones 39 seems to be useful intermediates to fully aromatic thieno[3,4-c] thiophenes. Such derivatives represent a $\pi$-heteropentalene system with tetracovalent sulfur nucleus and are investigated from synthetic and theoretical point of view. $^{114,115}$

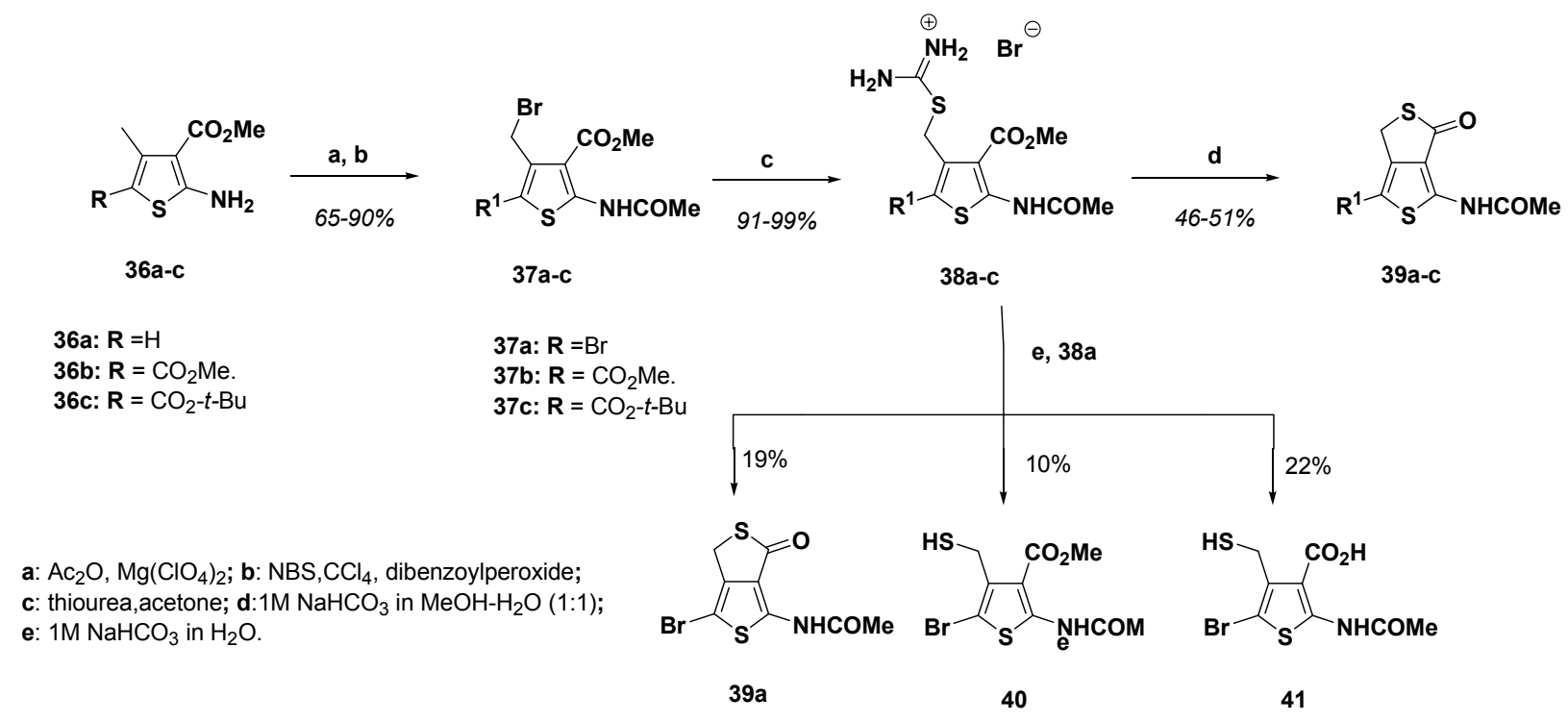

\section{Scheme 17}

\subsection{Synthesis of substituted thieno[2,3-b]pyrroles}

Other type of bicyclic 5:5 heteropentalene systems with two heteroatoms in each ring ${ }^{114,115}$ variously substituted thieno[2,3-b]pyrroles $\mathbf{4 6}$ can be synthesized through 2phenylaminothiophenes 44 . The reaction reported by authors ${ }^{116}$ represents the one-pot synthesis in which the reaction sequence follows the Gewald reaction process. The synthesis starts with the condensation of activated methylene compounds $\mathbf{4 2}$ with alkyl or aryl isothiocyanates in a basic medium $\left(\mathrm{K}_{2} \mathrm{CO}_{3} / \mathrm{DMF}\right)$ giving salt - ketene $N, S$-acetal 43. The reaction continuation is based on the condensation of the intermediate salt ketene $N, S$-acetal $\mathbf{4 3}$ with the halide (ethyl bromoacetate or chloroacetonitrile) leading to the corresponding aminothio-acetal which smoothly undergo a Dieckmann type cyclization in basic medium at room temperature (Scheme 18). 2-Phenylaminothiophenes 44 were easily removed from the crude reaction mixture by rapid hydrolysis in water followed by filtration. The influence of the substituents of the isothiocyanate 
on its behavior during the condensation under basic conditions has been investigated. Phenyl isothiocyanate has been almost exclusively used for related studies and this choice could be explained by the availability of this compound, but above all it appeared to be the best candidate for this reaction. The replacement of phenyl isothiocyanate by other commercially available ones decreases dramatically the yields of thiophenes $\mathbf{4 6}$.

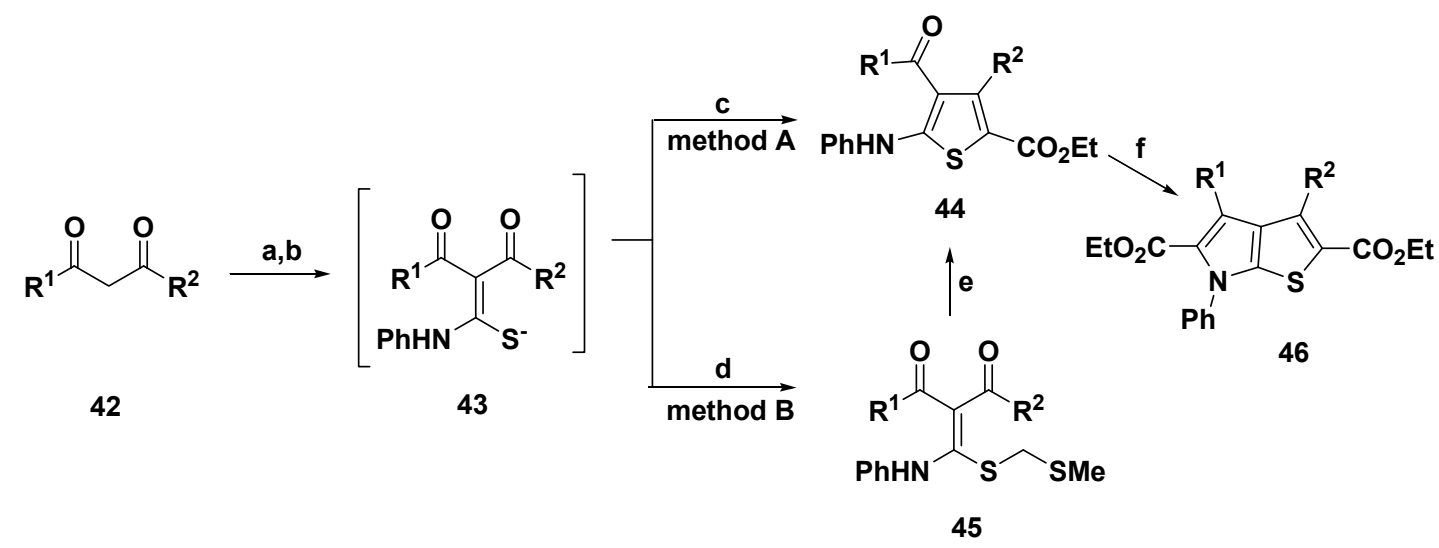

Method A: a: $\mathrm{K}_{2} \mathrm{CO}_{3}$, DMF, RT; b: PhNCS; c: $\mathrm{BrCH}_{2} \mathrm{CO}_{2} \mathrm{Et}, \mathrm{K}_{2} \mathrm{CO}_{3}$, DMF; f: $\mathrm{BrCH}_{2} \mathrm{CO}_{2} \mathrm{Et}, \mathrm{K}_{2} \mathrm{CO}_{3}$, acetone. Method B: a: $\mathrm{K}_{2} \mathrm{CO}_{3}$, DMF; b: PhNCS; d: Mel; e: $\mathrm{HSCH}_{2} \mathrm{CO}_{2} \mathrm{Et}, \mathrm{K}_{2} \mathrm{CO}_{3}$, EtOH.

\section{Scheme 18}

The same authors have published ${ }^{117}$ an improved two step method for the synthesis of $N$ phenylaminothiophenes $\mathbf{4 4}$, which is based on preparation and isolation ketene phenylamino methylthioacetals 45. These compounds were easily obtained in around $90 \%$ yields by methylation of the intermediate salt ketene $N, S$-acetals with methyl iodide (Scheme 18). The synthetic protocol for thieno[2,3-b]pyrroles, which is based on the reaction of 1,3-dicarbonyl compounds, can be applied also for preparation of thieno[2,3-b]thiophenes. As was reported in $^{118}$, the facile one-pot synthesis of polysubstituted thiophenes and thieno[2,3- $\left.b\right]$ thiophenes was completed through cyclization of $\alpha$-oxo ketene $(S, S)$-acetals.

\subsection{Synthesis of substituted thieno[2,3- $d]$ pyrimidines}

Substituted thieno[2,3- $d]$ pyrimidines are considered to be an universal molecules in a structurebased drug design. ${ }^{119}$ Thieno[2,3- $d$ ]pyrimidine derivatives show pronounced antiinflammatory $^{120}$, anti-tumor ${ }^{121}$, radioprotective and anti-convulsing activity. ${ }^{122}$ The pharmacological versatility of the above system also present in substances with depressant or sedative properties ${ }^{123}$ and compounds used for therapy of malaria ${ }^{124}$, tuberculosis $^{125}$, Parkinson's disease $^{126}$ and other diseases were designed. ${ }^{127}$

Their synthesis relies on the annulation of pyrimidine ring to five-membered thiophenes. The substituted 2-aminothiophenes act as the most suitable synthetic precursors to various thieno[2,3$d$ ]pyrimidines. The versatility of this approach lies not only in the ease of controlled introduction of substituents to C-4 and C-5 position into a starting 2-aminothiophene derivative, but also in 
the ease of incorporation of different electrophilic substituents in the C-3 position that allows for variation of the substitution pattern of the pyrimidine portion of the desired thienopyrimidines. One of the important preparations of 2-aminothieno[2,3- $d$ ]pyrimidines was investigated by authors $^{128}$. From the symmetric ketone 47 the Gewald thiophene synthesis was conducted in a stepwise fashion through Knoevenagel-Cope condensation to give the intermediate $\mathbf{4 8}$ followed by base-promoted thiophene cyclization with sulfur. ${ }^{35-37}$ From the 2-aminothiophene-3carbonitrile 49a or methyl 2-aminothiophene-3-carboxylate 49b the annulation of pyridine was performed using common pyrimidine annelation with guanidine carbonate 50a or chloroformamidine hydrochloride 50b (Method A, Scheme 19). ${ }^{129}$ In a second approach the aldehyde derivative 49c was prepared first in three steps and then annelated under the same conditions as before (Method B, Scheme 19). The desired products 51a-c were obtained in variable yields $(20-80 \%)$ by both methods. Presented synthetic approach is relevant also for the preparation other biologically active thienopyrimidine structures.

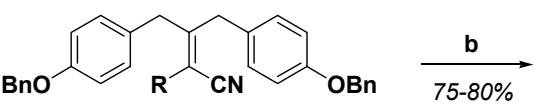

48a: $R=C N$

48b: $\mathrm{R}=\mathrm{CO}_{2} \mathrm{Me}$
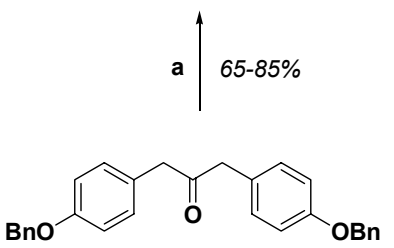

47

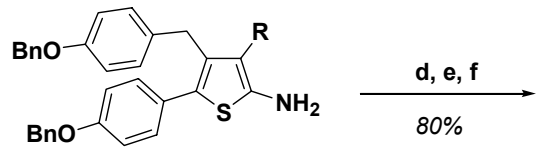

49a: $R=C N$

49b: $\mathrm{R}=\mathrm{CO}_{2} \mathrm{Me}$
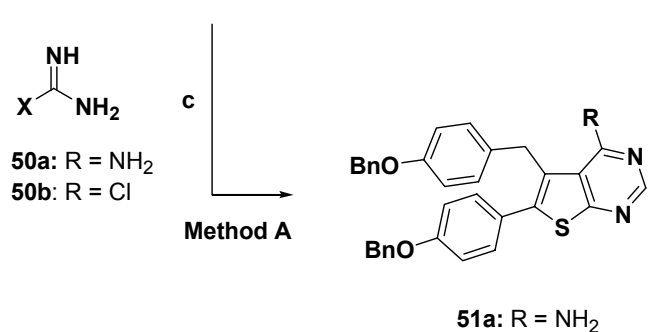

51b: $\mathrm{R}=\mathrm{OH}$

51c: $R=H$
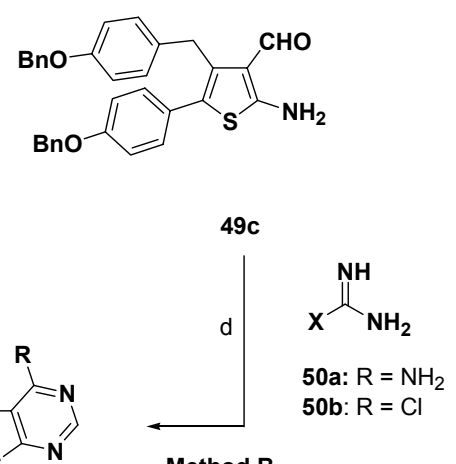

Method B

a:methylcyanoacetate or malononitrile, $\mathrm{NH}_{4} \mathrm{AcOH}, \mathrm{AcOH}, \mathrm{PhH}$, reflux; b: $\mathrm{S}_{8}, \mathrm{EtOH}, i-\mathrm{PrOH}, 60^{\circ} \mathrm{C}$;

Method A: c: $\mathbf{5 0 a}$ or $\mathbf{5 0 b}$, DMSO, $130-150^{\circ} \mathrm{C}$,

Method B: d: $\mathrm{Ph}_{3} \mathrm{CCl}, \mathrm{Et}_{3} \mathrm{~N}$; e: DIBAL-H, $-15^{\circ} \mathrm{C}$; $\mathbf{f}: \mathrm{Et}_{3} \mathrm{SiH}, \mathrm{TFA} ; \mathbf{f}: \mathbf{5 0 a}$ or $\mathbf{5 0 b}, \mathrm{DMSO}, 130-150{ }^{\circ} \mathrm{C}$.

\section{Scheme 19}

\subsection{Synthesis of substituted thieno[2,3-b]pyridines}

4-Oxo-4,7-dihydrothieno[2,3-b]pyridine-5-carbonitriles such as compound $\mathbf{5 3}$ are important intermediates in the synthesis of thieno[2,3- $b$ ] pyridine-5-carbonitrile kinase inhibitors. ${ }^{130,131}$

A facile three step synthesis of 4-oxo-4,7-dihydrothieno[2,3- $b$ ]pyridine-5-carbonitriles $\mathbf{5 3}$ from substituted 2-aminothiophene-3-carboxylate esters 7 was developed. ${ }^{132}$ The key step of the synthesis is a thermally promoted elimination/decarboxylation followed by nucleophilic cyclization of $\mathbf{5 2}$ to give fused thieno-dihydropyridines 53 (Scheme 20) in good yields (Table 10). 

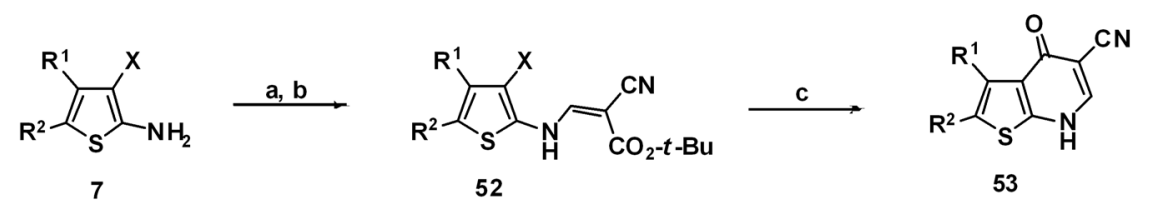

a:DMF-DMA, $100^{\circ} \mathrm{C}, 2 \mathrm{~h}$; b: $t$-Bu-cyanoacetate, $t$-BuOH, $2-8$ days;

c. $\mathrm{PhOPh}, 255^{\circ} \mathrm{C}, 2 \mathrm{~h}$.

\section{Scheme 20}

Table 10. Yields of synthesis of the acrylates $\mathbf{5 2}$ and fused thieno-dihydropyridines $\mathbf{5 3}$

\begin{tabular}{ccccc}
\hline $\mathrm{R}^{1}$ & $\mathrm{R}^{2}$ & $\begin{array}{c}\mathrm{X} \\
\text { (for 7, 52) }\end{array}$ & $\begin{array}{c}\text { Yield (\%) of } \\
52\end{array}$ & $\begin{array}{c}\text { Yield (\%) of } \\
\end{array}$ \\
& & & & 53 \\
\hline $\mathrm{H}$ & $\mathrm{H}$ & $\mathrm{CO}_{2} \mathrm{Me}$ & 78 & 91 \\
$\mathrm{H}$ & $\mathrm{Me}$ & $\mathrm{CO}_{2} \mathrm{Et}$ & 64 & 85 \\
$\mathrm{H}$ & $i-\mathrm{Pr}$ & $\mathrm{CO}_{2} \mathrm{Et}$ & 73 & 78 \\
$\mathrm{Me}$ & $\mathrm{H}$ & $\mathrm{CO}_{2} \mathrm{Me}$ & 53 & 86 \\
$\mathrm{Et}$ & $\mathrm{H}$ & $\mathrm{CO}_{2} \mathrm{Et}$ & 33 & 88 \\
$\mathrm{Ph}$ & $\mathrm{H}$ & $\mathrm{CO}_{2} \mathrm{Et}$ & 53 & 90 \\
$\mathrm{Bn}$ & $\mathrm{H}$ & $\mathrm{CO}_{2} \mathrm{Me}$ & 70 & 79 \\
$\mathrm{Me}$ & $\mathrm{Me}$ & $\mathrm{CO}_{2} \mathrm{Me}$ & 69 & 91 \\
$\mathrm{H}$ & $4-\mathrm{F}^{-\mathrm{C}_{6} \mathrm{H}_{4}}$ & $\mathrm{CO}_{2} \mathrm{Et}$ & 23 & 87 \\
$\mathrm{Me}$ & $4-\mathrm{F}_{6} \mathrm{C}_{6} \mathrm{H}_{4}$ & $\mathrm{CO}_{2} \mathrm{Me}$ & 76 & 64 \\
$\mathrm{H}$ & $4-\mathrm{Cl}_{6} \mathrm{C}_{6} \mathrm{H}_{4}$ & $\mathrm{CO}_{2} \mathrm{Et}$ & 70 & 72 \\
$\mathrm{H}$ & $4-{\mathrm{Br}-\mathrm{C}_{6} \mathrm{H}_{4}}_{\mathrm{CO}_{2} \mathrm{Et}}^{4-\mathrm{CH}_{3} \mathrm{O}-}$ & $\mathrm{CO}_{2} \mathrm{Me}$ & 31 & 77 \\
$\mathrm{H}$ & 42 & 99 \\
& $\mathrm{C}_{6} \mathrm{H}_{4}$ & & & \\
$\mathrm{H}$ & $2-$ furyl & $\mathrm{CO}_{2} \mathrm{Et}$ & 55 & 77 \\
\hline
\end{tabular}

\section{Applications of 2-aminothiophenes in drug design, optoelectronics and dyes}

Substituted 2-aminothiophenes represents a category of an important precursors broadly employed in the synthesis of pharmaceuticals, dyes and potential building blocks in materials chemistry.

\subsection{Synthesis of pharmaceuticals and drugs}

As we have discussed above (3.1.3), substituted thieno[2,3-d]pyrimidines 51 and thieno[2,3$b]$ pyridines 53 (3.1.4) exhibit valuable biological activity in numerous of diseases. Generally, substituted 2-aminothiophenes represent an exclusive group of structures widely exploited in 
medicinal chemistry and in the synthesis of active compounds for pharmaceutical applications. The ultimate position of substituted 2-aminothiophenes in this field comes from their advantageous properties - the thiophene ring as is bioisosteric replacement for phenyl group broadly present in an active drugs, the thiophene core exists in many natural and synthetic pharmaceuticals and moreover, they represent an active precursors in broad range of synthetic pathways towards compounds used in therapy. ${ }^{133,134}$

4.1.1 Synthesis of 3-deazathiamine. The synthesis of 3-deazathiamine 61 was effected in ten chemical steps, though it was necessary to prepare and isolate substituted 2-aminothiophene. ${ }^{135}$ As is outlined on Scheme 20, the synthesis starts from 3-acetyldihydrofuran-2(3H)-one 54 from which in four-step reaction sequence including the Gewald's stepwise technique ${ }^{35-37}$ appropriate 2-aminothiophene 56 is achieved. Deamination of aminothiophene 56 via the bromide 57 and following cleavage with zinc(0) in acidic media to afford derivative $\mathbf{5 8}$ was very efficient, displaying none of side reactions. Conversion of formed ester $\mathbf{5 8}$ to final 3-deazathiamine $\mathbf{6 1}$ was accomplished in four subsequent steps isolating the crucial intermediates - aldehyde $\mathbf{5 9}$ and nitrile 60. The readily available and inexpensive starting materials and reagents, and the lack of protection and de-protection steps make this synthesis very fashionable (Scheme 21). ${ }^{135}$

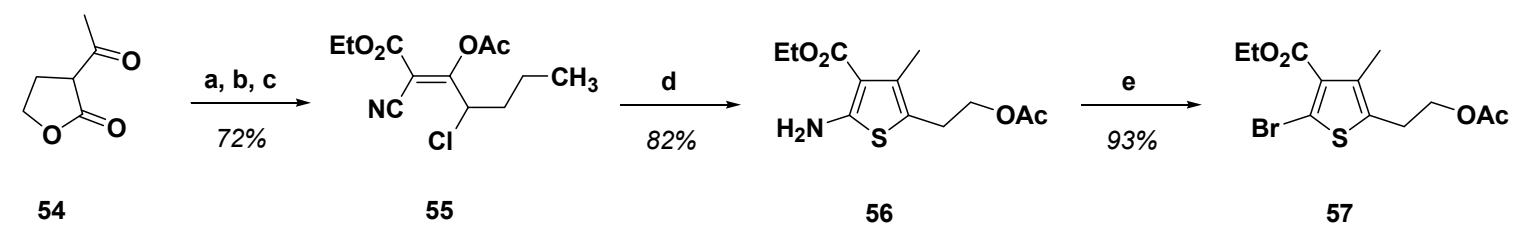

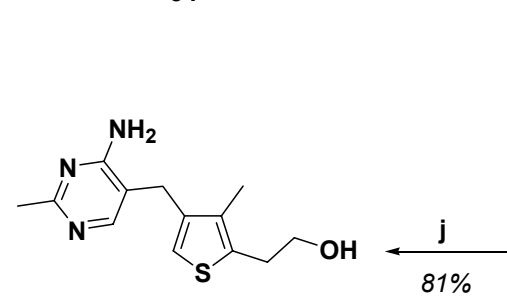

61

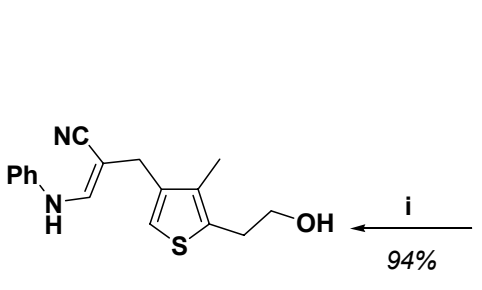

60

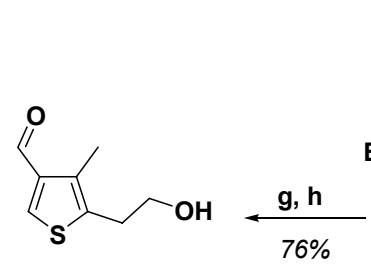

59

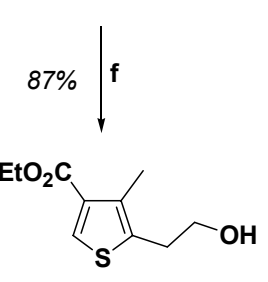

58

a: $\mathrm{SO}_{2} \mathrm{Cl}_{2}$; b:AcOH, $\mathrm{HCl}, \mathrm{Ac}_{2} \mathrm{O}$; $\mathbf{c}: \mathrm{NCCH}_{2} \mathrm{CO}_{2} \mathrm{Et}, \mathrm{AcONH}_{4}, \mathrm{AcOH}, \mathrm{PhMe}$; d: $\mathrm{NaSH}, \mathrm{EtOH} ; \mathbf{e}: \mathrm{CuBr}_{2}, t-\mathrm{BuONO}^{\mathrm{C}} \mathrm{CH}{ }_{3} \mathrm{CN}$; f: $\mathrm{Zn}, \mathrm{AcOH}$; g: $\mathrm{LiAlH}_{4}, \mathrm{Et}_{2} \mathrm{O} ; \mathbf{h}: \mathrm{MnO}_{2}, \mathrm{CHCl}_{3}$; i: $\mathrm{PhNH}-\left(\mathrm{CH}_{2}\right)_{2} \mathrm{CN}, \mathrm{NaOMe}, \mathrm{DMSO}, \mathrm{MeOH} ; \mathbf{j}: \mathrm{CH}_{3} \mathrm{C}(=\mathrm{NH}) \mathrm{NH}_{2}, \mathrm{HCl}, \mathrm{NaOEt}, \mathrm{EtOH}$.

\section{Scheme 21}

Deazathiamine diphosphate (deaza-TDP, Figure 1) is an analogue of thiamine diphosphate (TDP, Figure 2), the biologically active for of thiamin (vitamin $\mathrm{B}_{1}$ ), with a neutral thiophene replacing positively charged thiazolium ring. TDP is co-enzyme present in a number of enzymes, including pyruvate decarboxylase, transketolase, pyruvate oxidase. 


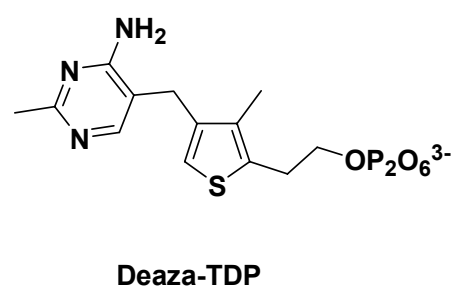

Figure 1

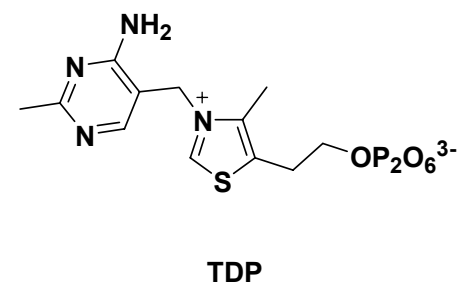

\section{Figure 2}

4.1.2 Synthesis of thieno[2,3-d][1,3] oxazin-4-ones as inhibitors of human leukocyte elastaze. A series of thieno[2,3-d][1,3] oxazin-4-ones 65 was synthesized and evaluated in vitro for inhibitory activity toward Human Leukocyte Elastaze (HLE). The strategy presented by authors $^{136,137}$ is based on the replacement of the benzene ring in benzoxazinones by thiophene one. The study demonstrates the versatility of 2-aminothiophenes as a synthetic entry to serine protease-inhibiting, fused 1,3-oxazin-4-ones. The synthetic route to novel thieno[2,3d] [1,3] oxazin-4-ones 65 using alkyl 2-aminothiophene carboxylates 62 as a substrates exhibits a facile three step synthesis, as is presented on Scheme 22. Aminothiophenes $\mathbf{6 2}$ were converted to isothiocyanato-thiophenes $\mathbf{6 3}$ by the thiophosgene method. Deprotection of tertbutoxycarbonyl group resulted directly to ring closure of the intermediates isothiocyanatothiophenecarboxylic acids leading directly to $\mathbf{6 4 a , b}$. These key intermediates were alkylated with appropriate alkyl halides to furnish the final derivatives 65 (Scheme 22). ${ }^{136}$

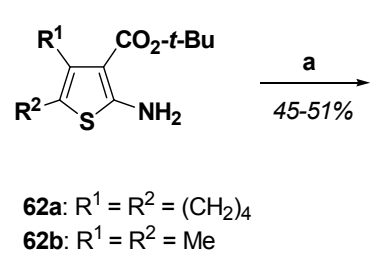

62a: $\mathrm{R}^{1}=\mathrm{R}^{2}=\left(\mathrm{CH}_{2}\right)$ 62. $R=R^{2}=M e$

a: $\mathrm{CSCl}_{2}, \mathrm{CaCO}_{3}, \mathrm{CH}_{2} \mathrm{Cl}_{2}, \mathrm{H}_{2} \mathrm{O}, 0^{\circ} \mathrm{C}$; b: TFA, $\mathrm{CH}_{2} \mathrm{Cl}_{2}, 0^{\circ} \mathrm{C}$; c: Mel or $\mathrm{RBr}, \mathrm{Na}_{2} \mathrm{CO}_{3}$, acetone, $\mathrm{RT}$.
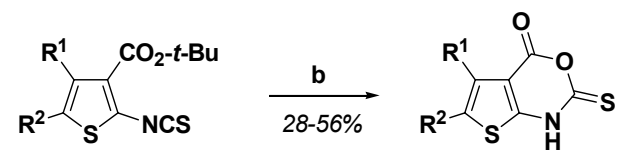

64a: $R^{1}=R^{2}=\left(\mathrm{CH}_{2}\right)_{4}$ 63b: $R^{1}=R^{2}=M e$ 64b: $R^{1}=R^{2}=M e$

\section{Scheme 22}

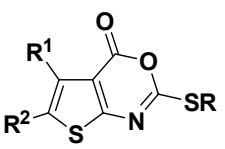

$$
\begin{aligned}
& \text { 65a: } R=M e, R^{1}=R^{2}=\left(\mathrm{CH}_{2}\right)_{4} \\
& \text { 65b: } R=M e R^{1}=R^{2}=M e \\
& \text { 65c: } R=E t, R^{1}=R^{2}=\left(\mathrm{CH}_{2}\right)_{4} \\
& \text { 65d: } R=\mathrm{Et}, \mathrm{R}^{1}=\mathrm{R}^{2}=\mathrm{Me} \\
& \text { 65e: } \mathrm{R}=\mathrm{CH}_{2} \mathrm{Ph}, \mathrm{R}^{1}=\mathrm{R}^{2}=\left(\mathrm{CH}_{2}\right)_{4} \\
& \text { 65f: } \mathrm{R}=\mathrm{CH}_{2} P h, \mathrm{R}^{1}=\mathrm{R}^{2}=\mathrm{Me} \\
& \text { 65g: } \mathrm{R}=\mathrm{CH}_{2} \mathrm{CO}_{2} \mathrm{Me}, \mathrm{R}^{1}=\mathrm{R}^{2}=\left(\mathrm{CH}_{2}\right)_{4} \\
& \text { 65h: } \mathrm{R}=\mathrm{CH}_{2} \mathrm{CO}_{2} \mathrm{Me}, \mathrm{R}^{1}=\mathrm{R}^{2}=\mathrm{Me}
\end{aligned}
$$


Extracellular HLE is a serine protease contained in the azurophilic granules of human neutrophil and has been shown to contribute to the pathogenesis of destructive lung diseases such are pulmonary emphysema, cystic fibrosis, adult respiratory distress syndrome and inflammatory disorders such as rheumatoid arthritis. For that reason, much attention is focused on the inhibition of HLE by low-molecular-weight inhibitors that might serve as therapeutic agents.

4.1.3 5-Substituted 2-aminothiophenes as $A_{1}$ Adenosine receptor allosteric enhancers. Adenosine is an important endogenous tissue-protective compound released during ischemia, hypoxia or inflammation. Four receptor subtypes $\left(\mathrm{A}_{1}, \mathrm{~A}_{2 \mathrm{~A}}, \mathrm{~A}_{2 \mathrm{~B}}, \mathrm{~A}_{3}\right)$ have been defined based on pharmacological properties. ${ }^{137,138}$ Considerable effort has been directed towards developing therapeutic agents targeting these receptors. ${ }^{139}$ The first allosteric enhancers acting at the adenosine $A_{1}$ receptor were reported in early 1990s. ${ }^{140,141}$ Since this initial discovery some molecules have been approved for use in the treatment of supraventricular tachycardia ${ }^{142}$, antiarrhythmic agent ${ }^{143}$ and cardio protective agent. ${ }^{144}$

Substituted 2-aminothiophenes of structure 66-69, with alkyl, aryl and cycloalkyl substituents in C-4 and C-5 position and aroyl substituent in C-3 position (Figure 3), maintained the best allosteric enhancer activity. ${ }^{145,146}$ The significant effort in the area of synthetic aminothiophenebased allosteric enhancer is directed to development and synthesis of adenosine receptor agonists with limited side-effects. ${ }^{13,100,101,145,146}$

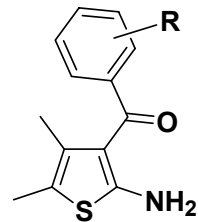

66

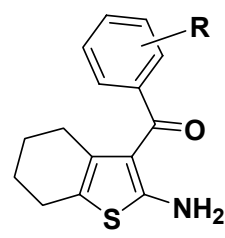

67

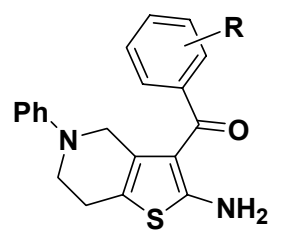

68

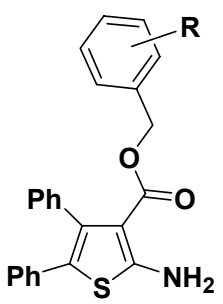

69

$\mathrm{R}=\mathrm{H}, 2-\mathrm{Cl}, 3-\mathrm{Cl}, 4-\mathrm{Cl}, 3,4-\mathrm{di}-\mathrm{Cl}, 3-\mathrm{CF}_{3}, 4-\mathrm{CF}_{3}, 4-\mathrm{CH}_{3}, 4-\mathrm{NO}_{2}, 4-\mathrm{CO}_{2} \mathrm{H}$, etc.

\section{Figure 3}

4.1.4 Other important pharmaceuticals developed from 2-aminothiophenes. The synthesis and antitumor activity of thieno[2,3-b]azepin-4-one based antineoplastic agents was reported. ${ }^{147}$ The meaningful structure-activity relationships have been established in monocarbonyl and dicarbonyl series of thieno[2,3-b]azepin-4-one 70, 71 (Figure 4) prepared by Dieckmann ring closure reaction in multistep reaction from substituted 2-aminothiophenes.

Cinnamyl derivatives of thieno[2,3- $d$ ] oxazinones 72 (Figure 5) inhibits herpes protease processing in HSV-2 infected cells. The synthesis and pharmacology of this series of derivatives was presented by authors ${ }^{148,149}$ from ethyl 2-amino-4-methylthiophene-3-carboxylate. 


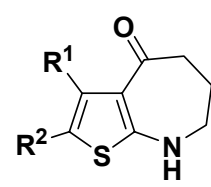

70

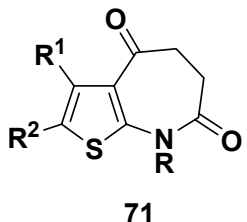

$\mathrm{R}^{1}=\mathrm{R}^{2}=\mathrm{Me}, \mathrm{R}^{1}=\mathrm{Ph}, \mathrm{R}^{2}=\mathrm{Me}$,

$\mathrm{R}=$ tosyl or benzoyl

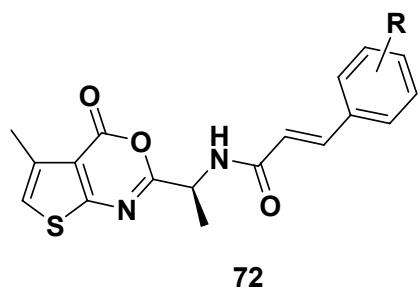

$\mathrm{R}=\mathrm{H}, 2-\mathrm{Cl}, 2-\mathrm{Br}, 2-\mathrm{Me}, 2-\mathrm{NO}_{2}$, 2-EtO, 4-CHO

\section{Figure 4}

Figure 5

Transglutaminases (TGases) are a family of $\mathrm{Ca}^{2+}$ dependent enzymes which are normally expressed at low levels in many different tissues and serve vital roles, such as blood clothing and epithelia formation. Some TGase isoenzymes are involved in diverse pathological conditions like celiac disease, atherosclerosis and neurodegenerative disorders. Thieno[2,3- $d]$ pyrimidine-4hydrazide derivatives related to structure 73 (Figure 6) were discovered as a moderately potent inhibitors of TGase-2 (tissue transglutaminase). ${ }^{150}$

The RNA polymerase holoenzyme is a proven target for antibacterial agents. A highthroughput screening program based on this enzyme from Staphylococcus aureus had identified a 2-ureido-thiophene-3-carboxylate 74 (Figure 7) as a low micromolar inhibitor. It displayed good antibacterial activity against $S$. aureus and $S$. epidermidis. Based on these author observations reported a synthesis of the number of analogs of $\mathbf{7 4}$ via the Gewald reaction and evaluated for cytotoxic activity against Rifampicin-resistant $S$. aureus. ${ }^{151}$

A novel class of thiophene-derived antagonists of the human hepatic glucagon receptor (hGCRG) has been discovered. ${ }^{152}$ The synthesis of derivatives based on the lead structure $\mathbf{7 5}$ (Figure 8) accomplished using the Gewald reaction. The further investigations of such structures are challenging in development of therapeutics of the diabetes mellitus. Diabetes mellitus is a condition characterized by chronically elevated levels of blood glucose caused by incorrect function of the hormone responsible for the hGCRG activation.

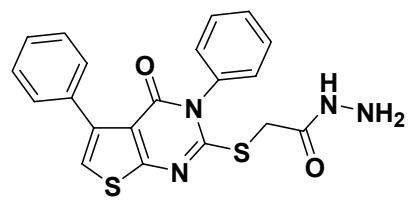

73

\section{Figure 6}




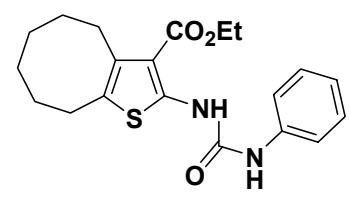

74

\section{Figure 7}

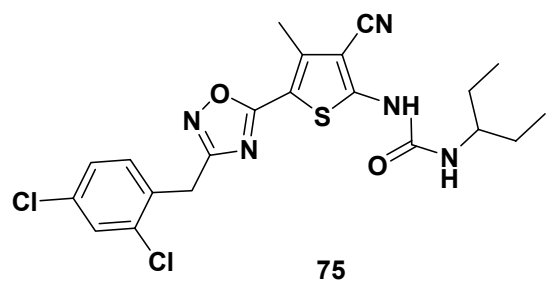

\section{Figure 8}

Because the structure-based drug design program through substituted 2-aminothiophenes has been investigated broadly, up to this date there are many other research works dealing with the synthesis, pharmacology and application of thiophene-based structures in medicinal chemistry. $7,12-14,36,37,51,69,100,101,119-127$ It is no doubt, that this area of Gewald-like thiophene derivatives exhibits the highest progress in a scope and utilization.

\subsection{Synthesis of building blocks for optoelectronics}

Oligothiophenes with well defined structures have recently received a great deal of attentions not only as a model compounds for conducting polymers, but also as a new class of functional $\pi$ electron systems. ${ }^{153}$ Since the initial discovery of organic compounds showing metallic conductivity, for which 2000 Nobel prize in chemistry was awarded, ${ }^{154-156}$ oligo- and polythiophenes have attracted much attention as advanced molecules with practical use in electronic devices ${ }^{157-160}$ and their potential application in field-effect transistors, ${ }^{161}$ photovoltaic devices ${ }^{162}$ and organic electroluminescent devices. ${ }^{163}$

The employment of substituted 2-aminothiophenes in such areas represents the latest discovery showing a great promise in materials chemistry for the generation of novel oligo- and polythiophene structures.

4.2.1 Synthesis of thiophene-based azomethines. The authors ${ }^{164,165}$ have discovered a facile synthesis of substituted azometines by a condensation of diethyl 2,5-diaminothiophene-3,4dicarboxylate $\mathbf{7 6}$ with thiophene-2-carbaldehyde 77 or 5-(thiophen-2-yl)thiophene-2carbaldehyde 78 the appropriate azomethines 79-82 were achieved (Scheme 23). Synthesized azomethines 79-82 were investigated as promising structures able to transfer the energy because of their ,push-pull" nature. ${ }^{166-168}$ The synthesis of such structures represents surprisingly easy 
process with possibility of the further development of more complex azometines with various functional groups in the thiophene ring.

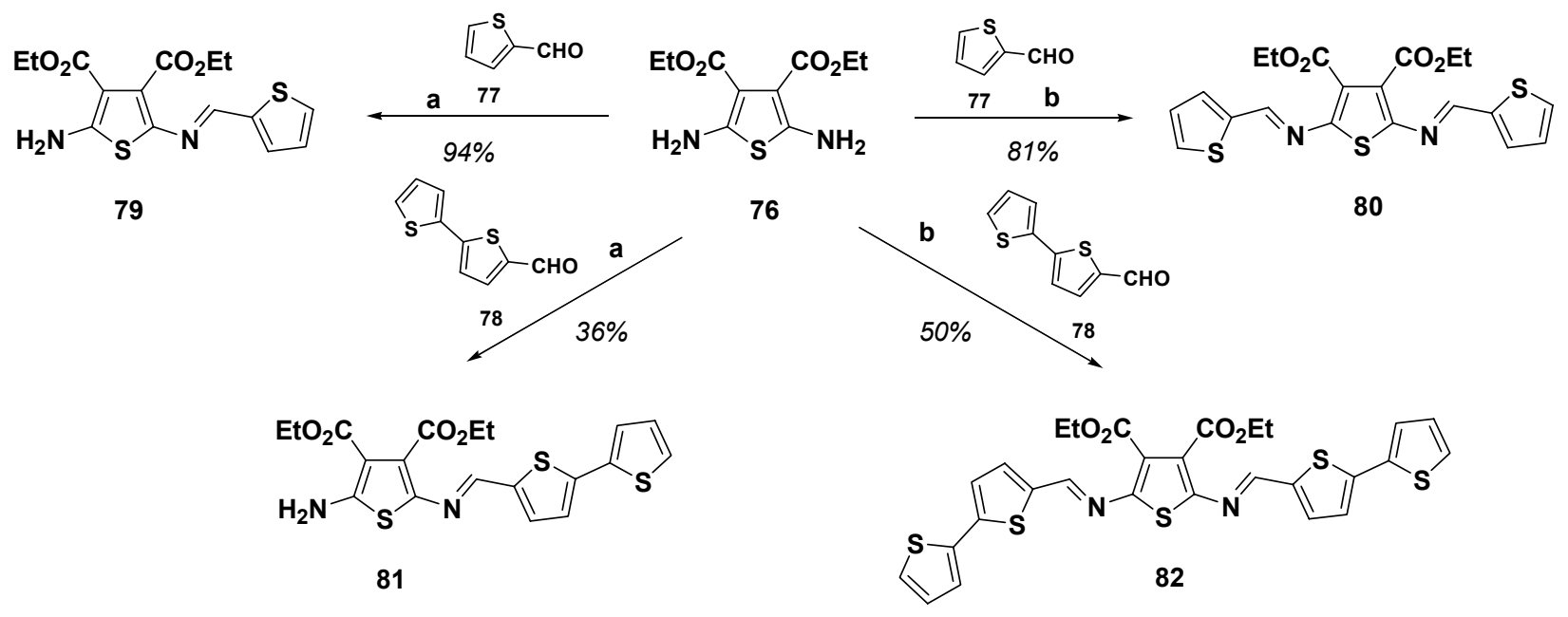

a: $n-\mathrm{BuOH}, 60^{\circ} \mathrm{C}, 1.0$ equiv. of 77 of $78, \mathbf{b}: n-\mathrm{BuOH}, 60^{\circ} \mathrm{C}, 2.0$ equiv. of 77 of 78

\section{Scheme 23}

4.2.2 Synthesis of $\pi$-conjugated thiophenes via Gewald reaction. The first report on the development and the use of substituted 2-aminothiophenes and the Gewald reaction was published by authors. ${ }^{59}$ The synthesis of $\beta$-aryl or $\beta$-heteroaryl substituted 2 -aminothiophenes 85 utilizing the Gewald reaction of substituted 3-oxopropanenitriles 83a-d and substituted acetonitriles $84 \mathrm{a}, \mathrm{b}^{57}$ as is presented on Scheme 24 .

The free amino group allowed the chain elongation and the growth of $\pi$-conjugated system to achieve structure with three thiophene units 86 (Figure 9) upon its modification via deamination reaction $^{38,39,82,135}$ followed by the Gewald reaction. The advantage of this process is in possibility of the prediction of hydrophilic or hydrophobic character of final structures with right choice of starting substrates bearing functional groups. 


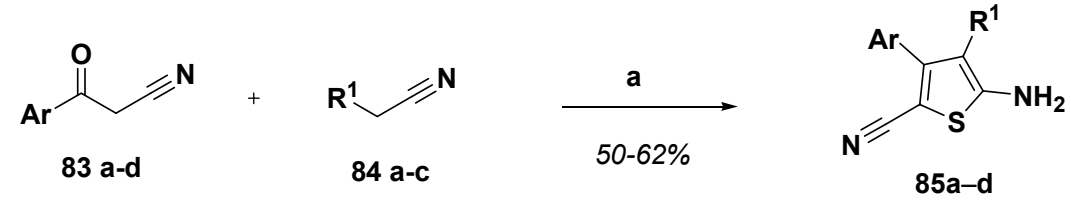

a: morpholine-polysulfide (MPS), $\mathrm{S}_{8}$, methanol

Product

Scheme 24

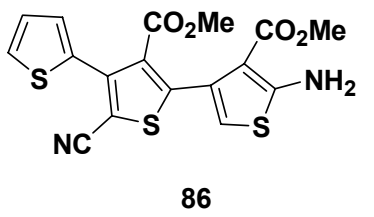

Figure 9

\subsection{Synthesis of some dispersed thiophene-based azo dyes}

Interests in the design of azo dyes containing heterocyclic moieties stem from their high degree of brightness compared to azo dyes derived from anilines. ${ }^{169-172}$ The 2-aminothiophene based azo dyes are known as dispersed dyes with excellent brightness shade of shade. This class of dyes was established as an alternative to more expensive anthraquinone dyes. ${ }^{173,174}$ The thiophene containing azo dyes have many advantages including a color deepening effect as an intrinsic property of the thiophene ring and small molecular structure leading to better dye ability. ${ }^{175,176}$ Increasing the electron-withdrawing strength of the substitutents on the thiophene ring resulted in batochromic shifts. Additionally, the sulfur atom plays a decisive role by acting as an efficient electron sink as explained by valence band theory. ${ }^{177}$ The thiophene-based azo dyes 92 are obviously prepared by diazotizing of substituted 2-aminothiophenes 7 using nitrozyl sulfuric acid with appropriate couplers, such as 2,3-dihydroxynaphthalene $\mathbf{8 7}$, resorcinol $\mathbf{8 8}$, 2-(N- 
methylanilino)ethanol 89, 2-(N-ethylanilino)ethanol 90, 3-[(2-hydroxyethyl)phenylamino]propionitrile 91 according to Scheme 25.

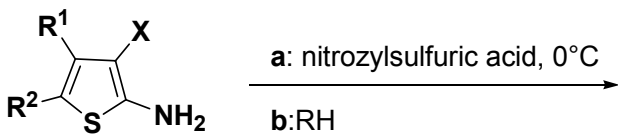

7

For couplers: $\mathrm{R}=$

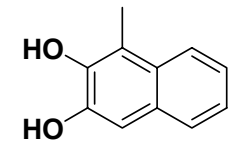

87

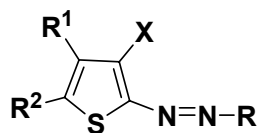

92
For 92:

$\mathrm{X}=\mathrm{CN}, \mathrm{CO}_{2} \mathrm{Et}, \mathrm{CONH}_{2}$, etc.

$\mathrm{R}^{1}=\mathrm{R}^{2}=$ alkyl, cycloalkyl, aryl or

$\mathrm{R}^{1}=$ alkyl, aryl and

$\mathrm{R}^{2}=\mathrm{CN}, \mathrm{CO}_{2} \mathrm{Et}, \mathrm{CONH}_{2}$, etc.

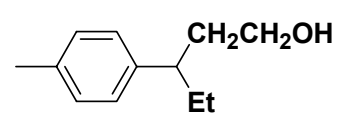

90<smiles>Cc1ccc(O)cc1O</smiles>

88

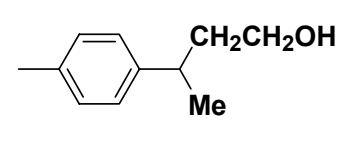

89

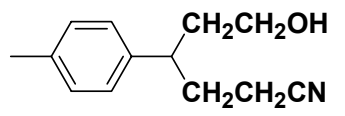

91

\section{Scheme 25}

A number of researchers studied azo disperse dyes derived form substituted 2aminothiophenes 90 in the dyeing of synthetic fibres, ${ }^{178-187}$ blended polyester wool fibres ${ }^{188,189}$ and also in optical data store devices. ${ }^{190}$

\section{Conclusions}

In this review we have extended the problems of synthesis of variety of substituted 2aminothiophenes and their scope and utilization. Thirty years after the famous chapter by R. K. Norris $^{25}$ and ten years of the last Gewald reaction review ${ }^{26}$ we felt the time was ripe for a fresh look at this field of heterocyclic chemistry. The review starts with an extensive introduction that discusses the most multidisciplinary areas of 2-aminothiophene research with inputs from medicine, pharmacology, chemistry, biology, biochemistry, materials science and physics. We have collected together detailed descriptions of selected important new reactions and works used Gewald reaction. The scope of presented work does not include all of the publications on the chemistry of substituted 2-aminothiophenes, but the most interesting studies in the subject areas are considered. The reader interested in the latter aspects can find further detailed information in the list of references. 


\section{Abbreviations}

Ac - acetyl; Ar - aryl; Bn - benzyl; Boc - tert-butyloxycarbonyl; Bu - butyl; DBU - 1,8diazabyciclo[5.4.0]undec-7-ene; DIBAL-H - diisobutylaluminum hydride; DIC - 1,3diisopropylcarbodiimide; DMAP - 4-dimethylaminopyridine; DIPEA -diisopropylethylamine; DMF - N,N-dimethylformamide; DMF-DMA - dimethylformamide dimethylacetal; DMSO dimethylsulfoxide; EDG - electron-donating group; EWG - electron-withdrawing group; Et - ethyl; equiv. - equivalent; $\mathrm{h}$ - hour; hGCRG - hepatic glucagon receptor; HMDS hexamethyldisilazane; HLE - human leukocyte elastaze; Me methyl; min - minute; MPS morpholine polysulfide; NBS - N-bromosuccimide; PEG - polyethylene glycol; $\mathrm{Ph}$ - phenyl; $\mathrm{Pr}$ - propyl; PS - polystyrene; Ref. - reference; RNA - Ribonucleic acid; RT - room temperature; TEAHFP - tetraethylammonium hexafluorophosphate; TDP - thiamin diphosphate; TFA trifluoroacetic acid.

\section{Acknowledgments}

The support of this work by grants VEGA 1/0229/10, VEGA 1/0266/10, VEGA 1/0774/08, VEGA 1/0817/08, VEGA 1/1005/09 and VVCE 0004-07 and FaF UK/16/2010 is acknowledged.

\section{References}

1. Heyde, C.; Zug, I.; Hartmann, H. Eur. J. Org. Chem. 2000, 3273.

2. Noack, A.; Hartmann, H. Tetrahedron 2002, 58, 2137.

3. Jagodzinski, T. S. Chem. Rev. 2003, 103, 197.

4. Zeika, O.; Hartmann, H. Synthesis 2004, 377.

5. Zeika, O.; Hartmann, H. Tetrahedron 2004, 60, 8213.

6. Yen, M. S.; Wang, I. J. Dyes Pigm. 2004, 61, 243.

7. Wu, C.; Decker, E. R.; Blok, N.; Bui, H.; You, T. J.; Wang, J.; Bourgoyne, A. R.; Knowles, V.; Berens, K. L.; Holland, G.W.; Brock, T. A.; Dixon, R. A. F. J. Med. Chem. 2004, 47, 1969.

8. Doré, K.; Dubus, S.; Ho, H. A.; Lévesque, I.; Brunette, M.; Corbeil, G.; Boissinot, M.; Boivin, G.; Bergeron, M. G.; Boudreau, D.; Leclerc, M. J. Am. Chem. Soc. 2004, 126, 4240.

9. Rost, C.; Karg, S.; Riess,W.; Loi, M. A.; Murgia, M.; Muccini, M. Appl. Phys. Lett. 2004, $85,1613$.

10. Vriezema, D. M.; Hoogboom, J.; Velonia, K.; Takazawa, K.; Christianen, P. C. M.; Maan, J. C.; Rowan, A. E.; Nolte, R. J. M. Angew. Chem., Int. Ed. 2003, 42, 772. 
11. Yu, H.; Pullen, A. E.; Büschel, M. G.; Swager, T. M. Angew. Chem., Int. Ed. 2004, 43, 3700 .

12. Tranberg, C. E.; Zickgraf, A.; Giunta, B. N.; Lütjens, H.; Figler, H.; Murphee, L. J.; Falke, R.; Fleisher, H.; Linden, J.; Scammels, P. J.; Olsson, R. A. J. Med. Chem. 2002, 45, 382.

13. Kourounakis, A. P.; van der Klein, P. A. M.; Ijzerman, A. P. Drug Dev. Res. 2000, 49, 227.

14. Duffy, J. L.; Campbell, E. L.; Liang, R.; Konteatis, Z. International Patent No WO 024065, 2004.; Chem. Abstr. 2004, 140, 287368.

15. Gewald, K. Angew. Chem. 1961, 73, 114.

16. Gewald, K. Chem. Ber. 1965, 98, 3571.

17. Gewald, K.; Schinke, E.; Böttcher, H. Chem. Ber. 1966, 99, 94.

18. Gewald, K.; Hoffmann, I. J. Prakt. Chem. 1969, 311, 402.

19. Gewald, K.; Kleinert, M.; Thiele, B.; Hentschel, M. J. Prakt. Chem. 1972, 314, 303.

20. Gewald, K. Gruner, M.; Hain, U.; Sueptity, G. Monatsh. Chem. 1988, 119, 985.

21. Frutos Hoener, A. P.; Henkel B.; Gauvin, J.-C. Synlett, 2003, 63.

22. Huang, W.; Li, J.; Tang, J.; Liu, H., Shen, J.; Jiang, H. Synth. Commun. 2005, 35, 1351.

23. Treu, M.; Karner, T.; Kousek, R.; Berger, H.; Mayer, M.; McConnell, D. B.; Stadler, A. J. Comb. Chem. 2008, 10, 863.

24. Hesse, S.; Perspicace, E.; Kirsch, G. Tetrahedron Lett. 2007, 48, 5261.

25. Norris, R. K. In Chemistry of Heterocyclic Compounds; Editor, Gronowitz, S.; Interscience, Part 2, 1986, pp 631-799.

26. Sabnis,R. W.; Rangnekar, D. W.; Sonawane, N. D. J. Heterocycl. Chem. 1999, 36, 333.

27. Benary, E. Chem. Ber. 1910, 43, 1943.

28. Gompper, R.; Kutter, E. Angew. Chem. 1962, 74, 251.

29. Gewald, K.; Schinke, E. Chem. Ber. 1966, 99, 2712.

30. Gewald, K.; Neumann, G. Chem. Ber. 1968, 101, 1933.

31. Gronowitz, S.; Fortea-Laguna, J. Ross, S.; Sjöberg, B.; Stjernström, N. E. Acta Pharm. Suecica 1968, 5, 563.

32. Cope, C. A.; Hofmann, C. M.; Wyckoff, C.; Hardenbergh, E. J. Am. Chem. Soc. 1941, 63, 3452.

33. Milart, P.; Wilamowski, J.; Sepiol, J. J. Tetrahedron 1998, 54, 15643.

34. Schatz, J. Thiophenes, Thiophene 1,1-dioxides, and Thiophene 1-oxides. In Science of Synthesis, Houben-Weyl Methods of Molecular Transformations, Volume 9, Georg Thieme Verlag Eds.; Stuttgart, Germany, 2004, pp. 24.

35. Sabnis, R. W. Sulfur Rep.1994, 16, 1.

36. Adachi, I.; Yamamori, T.; Hiramatsu, Y.; Sakai, K.; Mihara, S.-I.; Kawakami, M.; Masui, M.; Uno, O.; Ueda, M. Chem. Pharm. Bull. 1988, 36, 4389.

37. Naumann, B.; Böhm, R.; Fülöp, F.; Bernáth, G. Pharmazie 1996, 51, 4.

38. Hallas, G.; Choi, J.-H. Dyes Pigm. 1999, 42, 249.

39. Shvedov, V. I.; Ryzhkova, B. K.; Grinev, A. N. Khim. Geterotsikl. Soed. 1967, 6, 1010.

40. Eck, D. L.; Stacy, G. W. J. Tetrahedron Lett.. 1967, 8, 5201. 
41. Gewald, K.; Kleinert, M.; Thiele, B.; Hentschel, M. J. Prakt. Chem. 1972, 314, 303.

42. Hromátka, O.; Binder, D.; Stanetty, P.; Marischler, Monatsh. Chem. 1976, 107, 233.

43. Gronowitz, S. Thiophene and its derivatives. In Heterocyclic Compouds, John Wiley \& sons Eds.; New York, US, 1985, Part 1, 1-213.

44. Gewald, K.; Gruner, M.; Hain, U; Süptitz, G. Monatsh. Chem. 1988, 119, 985.

45. Schäfer, H.; Gewald, K. Monatsh. Chem. 1989, 120, 315.

46. Rehwald, M.; Gewald, K.; Bötcher, G. Heterocycles 1997, 45, 493.

47. McKibben, B. P.; Cartwright, C. H.; Castelhano, A. L. Tetrahedron Lett. 1999, 40, 54715474.

48. Pinto, I. L.; Jarvest, R. L.; Serafinowska, H. T. Tetrahedron Lett. 2000, 41, 1597.

49. Robin, A.; Meslin, J. C.; Deniaud, D. Synthesis 2004, 1633.

50. Tormyshev, V. M.; Trukhin, D. V.; Rogozhnikova, O. Yu.; Mikhalina, T. V.; Troitskaya, T. I.; Flinn, A. Synlett 2006, 2559.

51. Özbek, H.; Veljkovics, I. S.; Reissig, H.-U. Synlett 2008, 3145.

52. Hoffman, R. A.; Gronowitz, S. Ark. Kemi 1960, 16, 515.

53. Stacy, G. W.; Eck, D. L. Tetrahedron Lett. 1967, 5201.

54. Eck, D. L.; Stacy, G.W. J. Heterocycl. Chem. 1969, 147.

55. Elguero, J.; Marzin, C.; Katritzky, A. R.; Linda, P. The Tautomerism of Heterocyclic Compounds, Academic Press, New York, 1976.

56. Brandsma, L.; Vvedensky,V. Y.; Nedolya, N. A.; Tarasova, O. A.; Trofimov, B. A. Tetrahedron Lett. 1998, 39, 2433.

57. Gudriniece, E.; Pālītis, Ē.; Bārkane, V. Latvijas. A. V. Izv. AN Lat. SSR 1983, 5, 614.

58. Barnes, D. M.; Haight, A. R.; Hameury, T.; McLaughlin, M. A.; Mei, J.; Tedrow, J. S.; Riva Toma, J. D. Tetrahedron 2006, 62, 11311.

59. Puterová, Z.; Andicsová, A.; Végh, D. Tetrahedron 2008, 64, 11262.

60. Le Guillanton, G.; Do, Q. T.; Simonet, J. Bull. Soc. Chim. Fr. 1989, 126, 433.

61. Le Guillanton, G.; Do, Q. T.; Simonet, J. Bull. Soc. Chim. Fr. 1990, 127, 427.

62. Feroci, M.; Chiarotto, I.; Rossi, L.; Inesi, A. Adv. Synth. Catal. 2008, 350, 2740.

63. Kanbara, T.; Kawai, Y.; Hasegawa, K.; Morita, H.; Yamamoto, T. J. Polym. Sci.: Part A: Polym. Chem. 2003, 39, 3739.

64. Zavarzin, I. V.; Yarovenko, V. N.; Shirokov, A. V.; Smirnova, N. G.; Es'kov, A. A.; Krayushkin, M. M. Arkivoc 2005, 13, 205.

65. Cohen, M. P.; D’Sidocky, R. M. US Patent No 4873291, October 1989.

66. Litvinov, V. P. Russ. Chem. Rev. 1999, 68, 39.

67. Gewald, K.; Schill, W. J. J. Prakt. Chem. 1971, 313, 678.

68. Milart, P.; Wilamowski, J.; Sepioł, J. J. Tetrahedron 1998, 54, 15643.

69. Katano, K.; Shitara, E.; Shimizu, M.; Sasaki, K.; Miura, T.; Isomura, Y.; Kawaguchi, M.; Shokichi, O.; Tsuruoka, T. Bioorg. Med. Chem. Lett. 1996, 6, 2601.

70. Noravyan, A. S.; Mkrtchyan, A. P.; Dzagatspanyan, I. A.; Nazaryan, I. M.; Akopyan, N. E.; Vartanyan, S. A. Pharm. Chem. J. 1977, 11, 1038. 
71. Elslager, E. F.; Jacob, P.; Werbel, L. M. J. Heterocycl. Chem. 1972, 9, 775.

72. Arya, V. P.; Shenoy, S. V. Indian J. Pharm. 1976, 14B, 766.

73. Arya, V. P. Indian J. Pharm. 1972, 10, 1141.

74. Arya, V. P.; Ghate, S. P. Indian J. Pharm. 1971, 9, 904.

75. Sharanin, Yu. A.; Promonenkov, V. K. Khim. Geterotsikl. Soed. 1980, 10, 1564.

76. Mitsui Toatsu Chemicals: Japan Kokai 6001, 180, 8501; Chem. Abstr. 1985, 103, 53950m.

77. Pavlovičová, R.; Mináriková, J.; Hudecová, D.; Végh, D. Chem. Pap. 1997, 51, 437.

78. Zhang, H.; Yang, G.; Chen, J.; Chen, Z. Synthesis 2004, 3055.

79. Matloubi-Moghaddam, F.; Zali-Boinee, H. Tetrahedron Lett. 2003, 44, 6253.

80. Matloubi-Moghaddam, F.; Zali-Boinee, H. Tetrahedron Lett. 2004, 60, 6085.

81. Matloubi-Moghaddam, F.; Ghaffarzadeh, M. Synth. Commun. 2001, 31, 317

82. Michell, R. H; Iyer, V. S. J. Am. Chem. Soc. 1996, 118, 722.

83. Hu, Y.; Chen, Z.- C.; Le, Z. - G.; Zheng, Q. - G. Synth Commun. 2004, 34, 3801.

84. Wang, S. S. J. Am. Chem. Soc. 1973, 95, 1378.

85. Castanedo, G. M.; Sutherlin, D. P. Tetrahedron Lett. 2001, 42, 7181.

86. Loupy, A. Microwaves in Organic Synthesis; Wiley-VCh, Weinheim, 2002.

87. Tierney, J.; Lindstrom, P. Microwave Assisted Organic Synthesis; Blackwell, London, 2005.

88. Robba, M.; Lecomte, J. M.; Sevricourt, M. C. Bull. Soc. Chim. Fr. 1974, 2864.

89. Sridhar, M.; Rao, R. M.; Baba, N. H. K.; Kumbhare, R. M. Tetrahedron Lett. 2007, 48, 3171.

90. Blass, B. E. Tetrahedron 2002, 58, 9301.

91. Kabalka, G. W.; Wang, L.; Namboodiri, V.; Pagni, R. M. Tetrahedron Lett. 2000, 41, 5151.

92. Yadav, V.; Babu, K. G.; Mittal, M. Tetrahedron 2001, 57, 7047.

93. Kabalka, G. W.; Wang, L.; Pagni, R. M. Synlett 2001, 108.

94. Blass, B. E.; Harris, C. L.; Portlock, D. E. Tetrahedron Lett. 2001, 42, 1611.

95. Rissafi, B.; El Louzi, A.; Loupy, A.; Petit, A.; Soufiaou, M.; Tétouani, S. F. Eur. J. Org. Chem. 2002, 2518.

96. Basu, B.; Das, P.; Bhuiyan, M. D. H.; Jha, S. Tetrahedron Lett. 2003, 44, 3817.

97. Chhibber, M. Synlett 2004, 197.

98. Yang, L.; Xu, L.-W.; Xia, C.-G. Tetrahedron Lett. 2005, 46, 3279.

99. Frutos-Hoener, A. P.; Henkel, B.; Gauvin, J.-Ch. Synlett 2003, 63.

100. Lütjens, H.; Zickgraf, A.; Figler, H.; Linden, J.; Olsson, R. A.; Scammells, P. J. J. Med. Chem. 2003, 46, 1870.

101. Aurelio, L.; Figler, H.; Linden, J.; Scammells, P. J. Bioorg. Med. Chemistry 2008, 16, 1319.

102. Lehnert, W. Tetrahedron 1973, 29, 635.

103. Eicher, T.; Hauptmann, S.; Speicher, A. Five-Membered Heterocycles, Chapter 5, Section 5.6: Thiophene. In The Chemistry of Heterocycles, Wiley-VCH, New York, US, 2003. 
104. King, W. J.; Nord, F. F. J. Org. Chem. 1949, 14, 638.

105. Wu, C.; Decker, E. R.; Blok, N.; Bui, H.; You, T. J.; Wang, J.; Bourgoyone, A. R.; Knowles, V.; Berens, K. L.; Holland,G. W.; Brock, T. A.; Dixon, R. A. F. J. Med. Chem. 2004, 47, 1696.

106. Doré, K.; Dubus, S.; Ho, H.; Lévesque, I.; Brunette, M.; Corbeil, G.; Boissinot, M.; Boivin, G.; Bergeron, M. G.; Boudreau, D.; Leclerc, M. J. Am. Chem. Soc. 2004, 126, 4240.

107. Rost, C.; Carg, S.; Reiss, W.; Loi, M. A.; Murgia, M.; Muccini, M. Appl. Phys. Lett. 2004, $85,1613$.

108. Vriezema, D. M.; Hoogboom, J.; Velonia, K.; Takazawa, K.; Christianen, P. C. M.; Maan, J. C.; Rowan, A. E.; Nolte, R. J. M. Angew. Chem., Int. Ed. 2003, 42, 772.

109. Yu, H.; Pullen, A. E.; Büschel, M. G.; Swager, T. M. Angew. Chem., Int. Ed. 2004, 43, 3700 .

110. Puterová, Z.; Végh, D.; Gottasová, R.; Végh, D. Arkivoc 2005, XII, 36.

111. Pal, R.; Murty, K. V. N. S. ; Mal, D. Synth. Commun. 1993, 23, 1555.

112. Végh, D.; Morel, J.; Decroix, B.; Zálupský, P. Synth. Commun. 1992, 22, 2057.

113. Amaresh, R.; Lakshmikantham, M. V.; Baldwin, J. W.; Cava, M. P.; Metzger, R. M.; Rogers, R. D. J. Org. Chem. 2002, 67, 2453.

114. Krutošíková, A. In Comprehensive in Heterocyclic Chemistry II; Editors Katritzky, A. R.; Rees, C. W.; Scriven, E. F. V.; Elsevier: Oxford, UK, 1996; Vol. 7, pp 1-47.

115. Krutošíková, A.; Gracza, T. In Comprehensive in Heterocyclic Chemistry III; Editors Katritzky, A. R.; Ramsden, C. A.; Scriven, E. F. V.; Taylor, R. J. K. Elsevier: Oxford, UK, 2008; Vol. 10, pp 1-64.

117. Sommen, G.; Comel, A.; Kirsch, G. Tertahedron Lett. 2002, 43, 257.

118. Wang, Y.; Dong, D.; Yang, Y.; Huang, J.; Ouyang, Y.; Liu, Q. Tetrahedron 2007, 63, 2724.

119. Rosowsky, A.; Mota, E. C.; Wright, J. E.; Freisheim, J. H.; Heusner, J. J.; McCormack, J. J.; Queener, S. F. J. Med. Chem. 1993, 36, 3102.

120. Santagati, A.; Modica, M.; Santagati, M. J. Heterocycl. Chem. 1994, 31, 1141.

121. Sasaki, S.; Cho, N.; Nara, Y.; Harada, M.; Endo, S.; Suzuki, N.; Furuya, Sh.; Fujino, M. J. Med. Chem. 2003, 46, 113.

122. Santagati, M.; Modica, M.; Santagati, A.; Spampinato, S. Pharmazie 1996, 51, 7.

123. Temple, D. L.; Yevich, J. P.; Covington, R. R.; Hanning, C. A.; Seidehamel, R. J.; Mackey, H. K.; Bartek, M. J. J. Med. Chem. 1979, 22, 505.

124. Rosowsky, A.; Chen, K. N. N.; Lin, M. J. Med. Chem. 1973, 16, 2073.

125. Kapustina, M. V.; Omelkin, Yu.; Kharizomenova, I. A.; Shvedov, V. I.; Felitis, L. Pharm. Chem. J. 1991, 25, 475.

126. Hirotsune, I.; Takashi, K.; Eisuke, N.; Hidetaka, K.; Masamichi, O.; Takashi, T.; Atsushi, N. PTC Int. Appl. WO 0262803, 2002.

127. Hafez, H. N.; El-Gazzar, A. B. A. Bioorg. Med. Chem. Lett. 2008, 18, 5222.

128. Zhang, M.; Harper, R. W. Bioorg. Med. Chem. Lett. 1997, 7, 1629. 
129. Harris, N. V.; Smith, C.; Bowden, K. J. Med. Chem. 1990, 33, 434.

130. Wu, B.; Boschelli, D. H.; Lee, J.; Yang, X.; Chaudhary, D. Bioorg. Med. Chem. Lett. 2009, $19,766$.

131. Tumey, L. N.; Boschelli, D. H.; Lee, J.; Chaudhary, D. Bioorg. Med. Chem. Lett. 2008, 18, 4420.

132. Tumey, L. N.; Bhagirath, N.; Wu, B.; Boschelli, D. H. Tetrahedron Lett. 2008, 49, 6850.

133. Davies-Jones, G. A. B.; in Meyler's side effects of Drugs, $11^{\text {th }}$ ed., ed. by Dukes, M. N. G.; Elsevier Science Publishers, New York, US, 1988.

134. Jarvest, R. L.; Pinto, I. L.; Ashman, S. M.; Dabrowski, C. E.; Fernandez, A. V.; Jennings, L. J.; Lavery, P.; Tew, D. G. Bioorg. Med. Chem. Lett. 1999, 9, 443.

135. Hawskey, D.; Griffin, D. A.; Leeper, F. J. J. Chem. Soc. Perkin Trans. 1, 2001, 144.

136. Gütschow, M.; Neumann, U. J. Med. Chem. 1998, 41, 1729.

137. Gütschow, M.; Kuerschner, L.; Neumann, U.; Pietsch, M.; Löser, R.; Koglin, N.; Eger, K. J. Med. Chem. 1999, 42, 5437.

138. Jacobson, K. A.; Gao, Z.-G. Nat. Rev. Drug. Disc. 2006, 5, 247.

139. Bruns, R. F.; Fergus, J. H. Mol. Pharmacol. 1990, 38, 939.

140. Bruns, R. F.; Fergus, J. H.; Coughenour, L. L.; Courtland, G. E.; Pugsley, T. A.; Dodd, J. H.; Tiney, F. Mol. Pharmacol. 1990, 38, 950.

141. Linden, J. Allosteric enhacement of adenosine receptor. In Purinergic Approaches in Experimental Therapeutics, ed. by Jacobson, K. A.; Jarvis, M. F., Eds. Wiley-Liss, New York, US, 1997; pp 85-97.

142. Lerman, B. B.; Belardinelli, L. Circulation 1991, 83, 1499.

143. Sorbera, L. A.; Castaner, J.; Martin, L.; Bayes, M. Drugs Future 2002, 27, 846.

144. Smits, G. J.; McVey, M.; Cox, B. F.; Perrone, M. H.; Clark, K. L. J. Pharmacol. Exp. Ther. 1998, 286, 611 .

145. Nikolakopoulos, G.; Figler, H.; Linden, J.; Scammells, P. J. Bioorg. Med. Chem. 2006, 14, 2358.

146. Fergusson, G. N.; Valant, C.; Horne, J.; Figler, M.; Flynn, B. L.; Linden, J.; Chalmers, D. K.; Sexton, P. M.; Christopoulos, A.; Scammels, P. J. J. Med. Chem. 2008, 51, 6165.

147. Koebel, R. F.; Needham, L. L.; DeWitt Blanton, C. J. Med. Chem. 1975, 18, 192.

148. Jarvest, R. L.; Connor, S. C.; Gorniak, J. G.; Jennings, L. J.; Serafinowska, H. T.; West, A. Bioorg. Med. Chem. Lett. 1997, 7, 1733.

149. Jarvest, R. L.; Pinto, I. L.; Ashman, S. M.; Dabrowski, Ch. E.; Fernandez, A. V.; Jenning, J. L.; Lavery, P.; Tew, D. G. Bioorg. Med. Chem. Lett. 1999, 9, 443.

150. Duval, E.; Case, A.; Stein, R.; Cuny, G. Bioorg. Med. Chem. Lett. 2000, 15, 1885.

151. Arhin, F.; Bélanger, O.; Ciblat, S.; Dehbi, M.; Delorme, D.; Dietrich, E.; Dixit, D.; Lafontaine, Y.; Lehoux, D.; Liu, J.; McKay, G. A.; Moeck, G.; Reddy, R.; Rose, Y.; Srikumar, R.; Tanaka, K. S. E.; Williams, D. M.; Gros, P.; Pelletier, J.; Parr, T. R.; Rafai Far, A. Bioorg. Med. Chem. Lett. 2006, 14, 5812. 
152. Duffy, J. L.; Kirk, B. A.; Konteatis, Z.; Campbell, E. L.; Liang, R.; Brady, E. J.; Candelore, M. R.; Ding, V. D. H.; Jiang, G.; Liu, F.; Qureshi, S. A.; Saperstein, R.; Szalkowski, D.; Tong, S.; Tota, L. M.; Xie, D.; Yang, X.; Zafian, P.; Zheng, S.; Chapman, K. T.; Zhang, B. B.; Tata, J. R. Bioorg. Med. Chem. Lett. 2005, 15, 1401.

153. Müllen, K.; Wegner, G. Electronic materials, The Oligomers Approach, Wiley-VCH, Weineheim, 1998.

154. Shirakawa, H. Synth. Metals 2002, 125, 3.

155. MacDiarmid, A. G. Synth. Metals 2002, 125, 11.

156. Heeger, A. J. Synth. Metals 2002, 125, 23.

157. Hoeben, F. J. M.; Jonkheijm, P.; Meijer, E. W.; Scenning, A. P. H. J. Chem. Rev. 2005, $105,1491$.

158. Constanzo, F.; Tonelli, D.; Scalmani, G.; Cornil, J. Polymer, 2006, 47, 6692.

159. Sonar, P.; Benmansour, H.; Geiger, T.; Schlüter, A. D. Polymer, 2007, 48, 4996.

160. Schueppel, R.; Schmidt, K.; Ulrich, C.; Schulze, K. Wynands, D.; Brédas, J. L.; Brier, E.; Reinold, E.; Bu, H. B.; Bauerle, P.; Maenning, B.; Pfeiffer, M.; Leo, K. Phys. Rev. B 2008, $77,08531$.

161. Garnier, F.; Hajlaoui, R.; Yassar, A.; Srivastava, P. Science 1994, 265, 1684.

162. Videlot, C.; Fichou, D. Synth. Metals 1999, 102, 885.

163. Geiger, F.; Stoldt, M.; Schweizer, H.; Bäuerle, P.; Umbach, E. Adv. Mater. 1993, 5, 922.

164. Dufrense, S.; Skene, W. G. Org. Lett. 2004, 6, 2949- 2952.

165. Pérez-Guarín, S. A.; Bourgeaux, M.; Dufrense, S.; Skene, W. G. J. Org. Chem. 2007, 72, 2631.

166. Dufrense, S.; Bourgeaux, M.; Skene, W. G. J. Mater. Chem. 2007, 17, 11667.

167. Bourgeaux, M.; Skene, W. G. Macromolecules 2007, 40, 1792.

168. Bourgeaux, M.; Pérez-Guarín, S. A.; Skene, W. G. J. Mater. Chem. 2007, 17, 972.

169. Yen, M. S.; Wang, I. J. Dyes Pigm. 2004, 63, 1.

170. Yen, M. S.; Wang, I. J. Dyes Pigm. 2004, 61, 2430.

171. Yen, M. S.; Wang, I. J. Dyes Pigm. 2004, 62, 171.

172. Griffiths, J. Review of Progress in Coloration 1981, 11, 37.

173. Hallas, G.; Chio, J.-H. Dyes Pigm. 1999, 40, 119.

174. Towns, A. D. Dyes Pigm. 1997, 33, 215.

175. Hallas, G.; Towns, A. D. Dyes Pigm. 1997, 33, 215.

176. Hallas, G.; Towns, A. D. Dyes Pigm. 1997, 35, 45.

177. Abd-El-Aziz, A. S.; Afifi, T. H. Dyes Pigm. 2006, 70, 8.

178. Maradiya, H. R.; Patel, V. S. Chem. Heterocycl. Comp. 2002, 38, 1324.

179. Maradiya, H. R.; Patel, V. S. J. Serb. Chem. Soc. 2002, 67, 17.

180. Maradiya, H. R. Turk. J. Chem. 2001, 25, 441

181. Hallas, G.; Towns, A. D. 1996, 32, 135.

182. Hallas, G.; Towns, A. D. Dyes Pigm. 1996, 33, 319.

183. Hallas, G.; Choi, J.-H. Dyes Pigm. 1999, 42, 249. 
184. Bhatti, H. S.; Seshadri, S. Dyes Pigm. 2004, 62, 83.

185. Sabnis, R. W.; Rangnekar, D. W. Dyes Pigm. 1989, 10, 295.

186. Afifi, T. H.; Sayed, A. Z. J. Soc. Dyers Colour. 1997, 113, 256.

187. Georgiadou, K. L.; Tsatsaroni, E. G. Dyes Pigm. 2002, 53, 73.

188. Afifi, T. H. Adv. Colour Sci. Technol. 2003, 6, 63.

189. Astrand, P. O.; Sommer-Larsen, P.; Hvilsted, S.; Ramanujan, P. S.; Bak, K. L.; Saver, S. P. A. Chem. Phys. Lett. 2000, 325, 115.

190. Selim, S. R.; Afifi, T. H. Adv. Colour Sci. Technol. 2001, 4, 82.

\section{Authors' biographies}

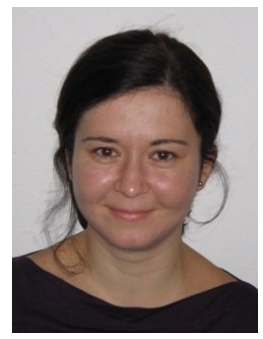

Zita Puterová was born in 1979 in Slovakia. Her M.S. in chemistry (2003) was earned at SS Cyril and Methodius University, Trnava, Slovakia under supervision of Prof. Alžbeta Krutošíková. Her Ph.D. degree in organic chemistry (2007) was received at Faculty of Chemical and Food Technology, Slovak University of Technology, Bratislava under supervision of Dr. Daniel Végh. During her doctoral studies (2004-2005) she joined the group of researchers at School of Chemistry at Dublin City University, Ireland and her postoctoral fellowship (2008) was held at Research Center for Nanometer-Scale and Advanced Material of Jagiellonian University, Krakow, Poland, both within Marie-Curie actions dealing with chemistry and physics of coordination compounds. She is currently research assistant in the Departmnet of Chemical Theory of Drugs, Faculty of Pharmacy, Comenius University in Bratislava. She has co-authored the publications concerning her research interests in the field of heterocyclic chemistry (aminothiophenes) and coordination chemistry (copper complexes).

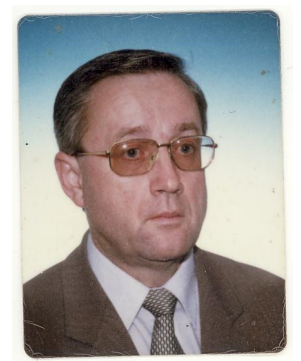

Daniel Végh was born in 1948 in Slovakia, received his M.S. degree in organic chemistry from Chemical University of Prag, Czech republic (1971, supervisor Prof. O. Cervinka). His Ph.D degree was earned at Slovak University of Technology (1977, Bratislava) and DrSc. degree at 
Comenius University (1990, Bratislava). Since 1991 he holds the position of senior research fellow in the Department of Organic chemistry at Faculty of Food and Chemical Technology STU, Bratislava. His main research interests are focused on the design and synthesis of novel $\pi$ conjugated organic materials in particular poly- and oligothiophenes and pyrroles and its fluorine substituted analogs. Synthetic strategies and new reactions, structure-property relationships, selfassembling properties and applications in organic electronics, solar cells and fotoionisation of water with visible lights are main highligts of his research. Results from his work have been published in about 148 peer-reviewed scientific papers and 62 patents.

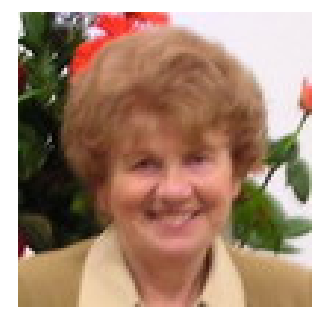

Alžbeta Krutošíková started her scientific carrier at Department of Organic Chemistry, Faculty of Chemical Technology, Slovak Technical University, in Bratislava. She completed her Ph.D. degree on the synthesis and reaction studies of arylfuran derivatives. During a postdoctoral stay in 1974-75 at University of East Anglia, she joined the group of Prof. A. R. Katritzky. She finished her habilitation in 1978 and D.Sc. at Comenius University Bratislava in 1988. Since 1991, she has been professor of organic chemistry at the Slovak Technical University in Bratislava. In 1999, she moved to University of SS. Cyril and Methodius in Trnava as Chair of the Department of Chemistry, where she holds a position of an emeritus professor nowadays. Her scientific achievements are focused on the synthesis of new heterocyclic compounds. To date, she has synthesized with her research group more than 500 new organic substances, mainly with heterocyclic structure, and participated on the quantitative studies of aromaticity of $\pi$-electronrich newly synthesized furo $[b]$ pyrroles. 